
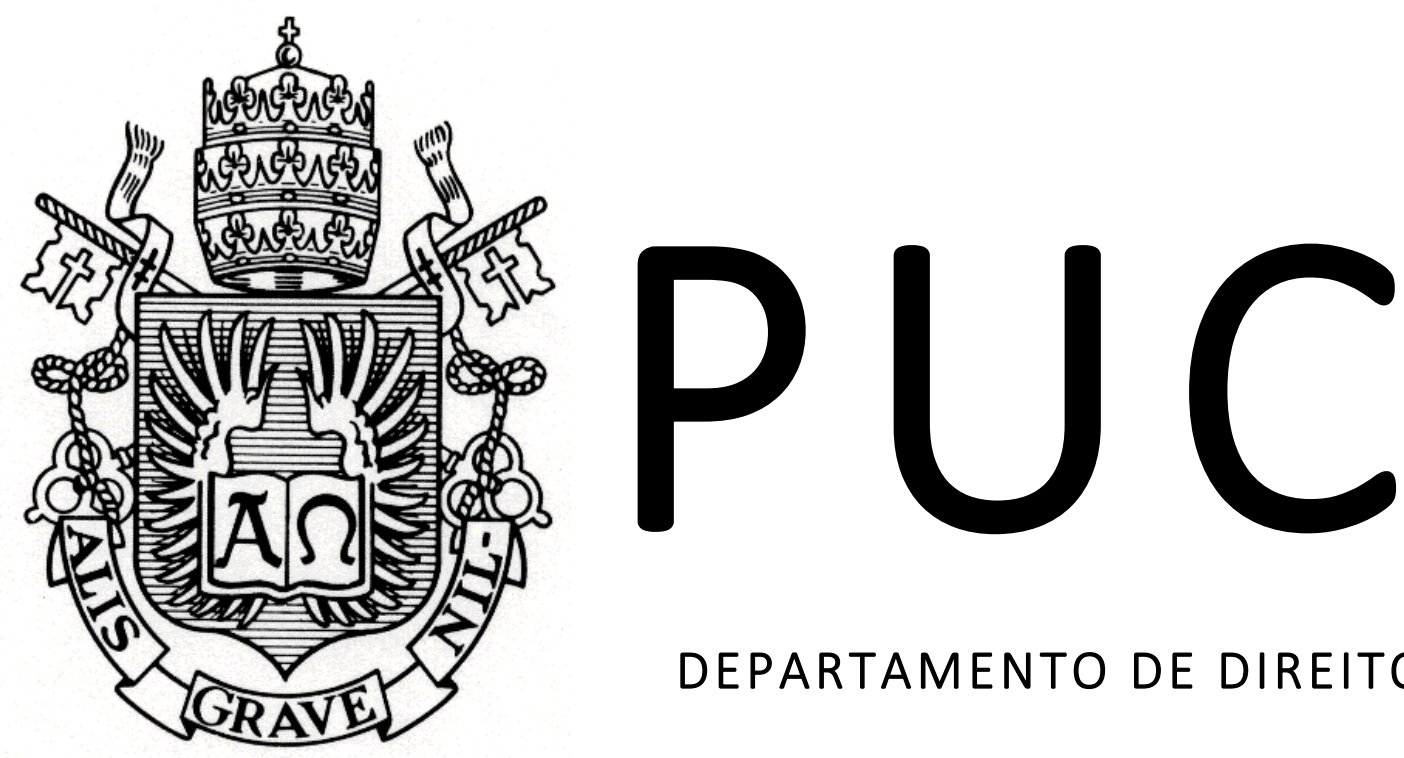

DEPARTAMENTO DE DIREITO

UM OUTRO MUNDO POSSÍVEL: ENSAIO SOBRE O COMUM, A MULTIDÃO E AS JORNADAS DE JUNHO

Por

JOSÉ MARINHO SÉVES SANTOS

ORIENTADOR: ADRIANO PILATTI

2016.2

PONTIFÍCIA UNIVERSIDADE CATÓLICA DO RIO DE JANEIRO

RUA MARQUÊS DE SÃO VICENTE, 225 - CEP 22451-900

RIO DE JANEIRO - BRASIL 


\title{
UM OUTRO MUNDO POSSÍVEL: ENSAIO SOBRE O COMUM, A MULTIDÃO E AS JORNADAS DE JUNHO
}

\author{
por \\ JOSÉ MARINHO SÉVES SANTOS \\ Monografia apresentada ao Departamento \\ de Direito da Pontifícia Universidade \\ Católica do Rio de Janeiro (PUC-Rio) para a \\ obtenção do Título de Bacharel em Direito.
}

Orientador: Adriano Pilatti

2016.2 
Dedico esse trabalho a memória de meus avós, Maria Irene e Américo, exemplos de perseverança $e$ superação 


\section{AGRADECIMENTOS}

Este ano que passou e, em especial, seu segundo semestre, foi um ano de grandes dificuldades e aprendizados. Não teria conseguido superá-la sem a ajuda de muitas pessoas. Agradecimento nenhum será capaz de expressas, de forma real, minha gratidão. Mas não custa tentar.

Em primeiro lugar, preciso agradecer aos meus pais, José Américo e Maria Ester. Acima de tudo, serei sempre grato por terem me dado aquilo que eu tenho de mais importante. Sem eles, não teria sido possível realizar este trabalho. Obrigado pelo apoio constante, mesmo quando não concordavam com o que eu fazia ou não entendendo muito bem minhas motivações.

Agradeço à minha irmã mais nova, Maria Carolina, pela companhia constante e inseparável em todos os momentos, em especial nos momentos de mais desespero e cansaço.

Agradeço também ao meu orientador e amigo, o professor Adriano Pilatti, o maior dos mestres que tive nesta faculdade. Certamente precisou de toda a sua paciência para aturar estes anos de pesquisa e aprendizados juntos, pelos quais eu sou muito grato.

Agradeço aos meus professores, por serem para mim exemplo de seriedade e rigor acadêmico. Agradeço, em especial, ao Alexandre e a Júlia, que, além da importância na minha trajetória, foram com certeza os que mais me marcaram.

Agradeço aos incansáveis guerreiros do Direitos em Movimento, grupo do qual tive o privilégio de participar desde o principio e cuja luta me inspira a buscar um mundo melhor, em especial ao Bruno, Matteo, Rafael, Virginia e, claro, minha grande amiga Fernanda. 
Por fim, como não poderia deixar de ser, agradeço a todos os meus amigos da PUC, sem os quais não teria chegado aqui, em especial à Carol, Priscila, Raphael e Waitz. Ter partilhado, ao longo desses cinco anos, do convívio diário fez da minha graduação uma experiência muito melhor, da qual eu certamente sentirei muitas saudades.

I was happy in the haze of a drunken hour, but heaven knows I'm miserable now. Os momentos difíceis deste último mês me presentearam com um verdadeiro time de amigos para todas as horas. Muitos de vocês já estavam aqui antes, é verdade, mas não foi até o mundo entrar em colapso que vocês apareceram, de forma salvadora. Bárbara, Bela, Carol, Leo e Marie, muito obrigado por tudo que vocês fizeram por mim nessas últimas semanas. A ajuda de vocês tem sido fundamental e a redescoberta dessa amizade foi, sem sombra de dúvidas, o ponto mais importante desse ano que passou. 


\section{RESUMO}

O objetivo do presente trabalho é articular os eventos das Jornadas de Junho de 2013 com a recente onda de lutas globais em torno do comum. Para isso, nós nos valemos da articulação de distintos conceitos: além do próprio conceito de comum, analisamos brevemente os conceitos de bens comuns; poder constituinte e multidão. Nosso objetivo não é conduzir um estudo aprofundado desses temas, o que seria impossível, dado a sua complexidade, mas sim destacar as suas características mais marcantes e que se relacionam de forma mais clara com os levantes de junho de 2013. Para isso, ao invés de partirmos do evento (Jornadas de Junho), passando pelo seu sujeito (a multidão, imbuia da potência do poder constituinte) e chegando, finalmente, ao seu objeto (o comum) optamos por fazer o caminho oposto. Desta forma, o primeiro capítulo de nosso trabalho será dedicado à análise do comum, partindo dos conceitos tradicionais de propriedade, passando pelos bens comuns e, por fim, diferenciando-o destes conceitos. Em seguida, passamos para a análise da multidão, partindo do conflito entre imanência e transcendência, no qual Negri fundamenta a modernidade, à evolução histórica do conceito de poder constituinte e, por fim, à própria multidão. Em nosso terceiro e último capítulo, estudaremos o desenrolar das jornadas de junho, partindo de seus antecedentes até o desenrolar dos fatos e as suas conclusões, buscando traçar paralelos entre o que foi visto nas ruas e a forma multitudinária de se manifestar.

Palavras-Chave: Bens Comuns; Comum; Pilhagem; Poder Constituinte; Imanência; Multidão; Resistência; Levantes; Protestos; Repressão. 


\section{SUMÁRIO}

INTRODUÇÃO

CAPÍTULO 1 - OS BENS COMUNS E O COMUM 12

1.1. PROPRIEDAdE E o DiReITo (BRASILEIRO) 12

1.2. Bens Comuns E o Comum 16

CAPÍTULO 2 - 0 PODER CONSTITUINTE E A MULTIDÃO 33

2.1. MODERNIDADE EM CONFLITO 33

2.2. 0 PODER CONSTITUINTE 39

2.2. 0 QUE É A MULTIDÃo? 44

CAPÍTULO 3 - OUTRO MUNDO BATE À PORTA: AS JORNADAS DE JUNHO 52

3.1. BREVES APONTAMENTOS SOBRE AS REVOLTAS MULTITUDINÁRIAS 52

3.2. ANTECEDENTES 55

3.3. J-13: O RUGIDO DA PLEBE 68

CONCLUSÃo 76

REFERÊNCIAS BIBLIOGRÁFICAS 79 
"All that is gold does not glitter,

Not all those who wander are lost;

The old that is strong does not wither,

Deep roots are not reached by the frost.

From the ashes a fire shall be woken,

A light from the shadows shall spring;

Renewed shall be blade that was broken,

The crownless again shall be king."

Bilbo Baggins 


\section{INTRODUÇÃO}

Nosso trabalho teve como objetivo identificar elementos que permitam configurar as Jornadas de Junho de 2013 como um movimento inserido no ciclo global de lutas multitudinárias pelo comum. Trata-se de empreitada nada simples e que envolve a articulação de conceitos que, embora se sobreponham em determinados aspectos, são distintos e densos. Por este motivo, apresentou-se um desafio, que era o de apresentar estes conceitos de forma concisa, mas sem ser superficial e, ao mesmo, que fosse densa o suficiente para que o nosso leitor compreendesse nosso esforço. Se fomos bem sucedidos, fica a cargo de você que nos lê agora.

Uma proposição nuclear em nosso trabalho é a de que a propriedade está no centro não só do ordenamento jurídico, mas também de toda a ordem social - vivemos na chamada republica della proprietà, segundo Hardt e Negri. Não é, portanto, espantoso para nós que a propriedade tenha inflexões políticas: a um determinado sistema corresponde uma forma majoritária de regulação do direito de propriedade - capitalismo/privada, socialismo/pública.

Essas são as definições tradicionalmente postas em jogo - a "falsa dicotomia" que domina o pensamento ocidental. Nós acreditamos, entretanto, que há uma terceira alternativa que não pertence nem público, nem ao privado: o comum, que é tudo aquilo socialmente produzido pela multidão.

A multidão, por sua vez, pode ser entendida como uma espécie de “sujeito do comum”. Ela não é definível, por ser composta pelo encontro de múltiplas subjetividades, sempre em permanente expansão. A multidão se auto-organiza e se compõe em torno da produção e defesa dos comuns. 
Esses são os conceitos nucleares de nosso trabalho. A partir deles, vamos desenvolver os demais temas que compõe a nossa pesquisa. Nosso primeiro capítulo é dedicado ao conceito de bens comuns e de comum.

Antes, todavia, de entrarmos nele, preferimos fazer uma pequena explicação - a luz da escola do law and economics - sobre o funcionamento do direito de propriedade dentro de um ordenamento jurídico capitalista. $\mathrm{O}$ fizemos porque entendemos que, por se tratar de uma visão antagônica àquela que trabalhamos, seria importante entender o seu funcionamento.

Depois, trabalhamos, rapidamente, a dinâmica da propriedade e dos bens no direito brasileiro de forma a estabelecermos um parâmetro de comparação com o direito italiano, visando o estudo dos bens comuns enquanto categoria jurídica - inovação do direito daquele país.

Antes, todavia, de lá chegarmos, ainda passamos, rapidamente, pelo desenvolvimento histórico do conceito, seguindo o seguinte roteiro: bens comuns no direito romano, no medievo, na era moderna, onde trabalhamos a pilhagem, até chegarmos no direito italiano, através da Comissão Rodotà.

Nesse caminho, um conceito conceito chave será a "pilhagem" utilizado por Ugo Mattei e Laura Nader para definir o que já havia sido chamado de "expropriação" - uma vez que sustentamos que o capitalismo se desenvolve e se sustenta a partir da expropriação dos comuns socialmente produzidos.

A Comissão Rodotà, por sua vez, foi uma tentativa de, através do ordenamento jurídico, conceituar e tutelar os bens comuns. Enquanto categoria jurídica, estes se definem não pela titularidade, mas sim pela funcionalidade em torno das garantias de direitos fundamentais.

Esse conceito se diferencia do comum, fundamentalmente, por ser um conceito jurídico e, por tanto, ter sua origem e definição atrelada à lei e por ela limitada. 
Depois, passamos para a análise da multidão. Para isso, tivemos que observar antes dois outros conceitos à luz da filosofia de Antonio Negri: a modernidade e o poder constituinte.

Em Negri, a modernidade é um conflito entre imanência e transcendência: a potência imanente tentando expandir-se e o poder transcendental, por sua vez, tentando limitá-lo. Embora vença a "modernidade transcendental", também dita hegemônica, ela não é capaz de sufocar a "modernidade imanente", a qual toma diferentes formas.

A manifestação dessa imanência é o poder constituinte. Em oposição ao conceito formulado pelos juristas, que é um poder anterior, finito e temporalmente limitado - ou seja, um poder transcendente - o poder constituinte em Negri é imanente, potente, infinito, expansível e molda o tempo a seu bel prazer.

Para chegar a este conceito, o pensador italiano traça um roteiro que atravessa diferentes períodos históricos e pensadores modernos. De Maquiavel ele tira, além de um conceito de política imanente, a natureza mutável do poder constituinte; de Harrington sua característica de contrapoder, ou seja, de resistência a partir da afirmação de novas propostas; da revolução americana ele retira a sua expansividade e, finalmente, da revolução russa - e da obra de Marx - Negri retira o seu caráter produtivo e cooperativo.

Daí chegamos a multidão, que é o sujeito no qual a potência do poder constituinte se manifesta. A multidão não é, nem poderia ser, povo, massa ou classe operária uma vez que ela é múltipla, permeável as diferentes singularidades e não se limita a uma única classe.

Com efeito, com a hegemonia do trabalho imaterial no capitalismo cognitivo, a multidão pode ser entendida não só como classe, mas também como a classe que detém a hegemonia na luta contra o capital. Como, pela ótica do trabalho imaterial, somos todos constantemente produtivos e, 
portanto, trabalhamos o tempo inteiro, todos pertencemos à multidão e, portanto, somos capazes de resistência.

Por fim, chegaremos ao final de nosso trabalho, estabelecendo a ligação entre os conceitos que trabalhamos e os acontecimentos que tiveram lugar no Brasil em Junho de 2013, em especial no Rio de Janeiro.

Para isso, examinaremos primeiro os antecedentes que levaram ao surgimento destes movimentos no Brasil, como foco especial na cidade do Rio de Janeiro, por ser o centro de nossa análise.

Depois partiremos para a narrativa dos fatos, buscando destacar neles os aspectos que nos permitem relacioná-los com os conceitos que expusemos ao longo de nosso trabalho.

Pretendemos, portanto, fazer um retrato daquele heróico junho de 2013, quando a plebe rugiu mais alto. A multidão tomou as ruas como um verdadeiro enxame, descentralizado, potente e produtivo. Naqueles meses, o tempo dobrou-se aos desígnios da multidão, deixando marcas que não serão esquecidas - e nem entendidas - tão cedo.

Aproveitamos para esclarecer que todas as traduções de obras em línguas estrangeiras citadas neste trabalho são de nossa autoria. 


\section{CAPÍTULO 1 - OS BENS COMUNS E O COMUM}

\subsection{Propriedade e o Direito (Brasileiro)}

O propósito deste capítulo é apresentar ao leitor uma breve definição do que são os conceitos de bens comuns e de comum, o objeto a ser tratado em nosso estudo. Para isto, optamos por estruturá-lo da seguinte forma: em primeiro lugar, faremos uma breve abordagem do conceito de propriedade; depois o estudaremos a luz do direito brasileiro e, por fim, apresentaremos os conceitos de bens comuns e comum, tentando estabelecer uma ligação entre estes e os tópicos anteriormente abordados.

Como dito em nossa introdução, a propriedade é um instituto central do Direito, em geral, e do ramo Civil, em particular, motivo pelo qual Perlignieri a define como "il pilastro degli ordinamenti", Tipicamente, a propriedade é definida como pública ou privada, sendo esta última uma das marcas dos regimes capitalistas, conforme colocado pelo eminente professor Caio Mário da Silva Pereira:

E conforme a influência do regime político sobre o modelamento da tipicidade dominial, o direito de nosso tempo conhece e disciplina a propriedade individual como padrão de direito subjetivo nos regimes capitalistas, e a ela se contrapondo e forcejando por se lhe sobrepor a propriedade coletiva predominante especialmente no que concerne aos bens de produção, vigentes nos regimes socialistas e nas chamadas repúblicas populares ${ }^{2}$.

\footnotetext{
${ }^{1}$ La proprietà si pone come uno dei fenomeni centrali per il suo stretto collegamento con quasi tutti gli istituti del diritto civile: dalla famiglia alle sucessioni, dall'impresa al lavoro e ai contrati (...) la proprietà, correlandosi alla libertà dal bisogno di ogni individuo, si presenta come il pilastro degli ordenamenti, tant'è che, ancora in epoche moderne, s'è reputato di poterla ascrivere ai diritti fondamentali e inviolabile dell'uomo. (grifo nosso). PERLINGIERI, Pietro. Manuale di Diritto Civile. 6a ed. Napoli: Edizioni Scientifiche Italiane. 2007. p. 173.

2 PEREIRA, Caio Mário da Silva. Instituições de Direito Civil. Direitos Reais IV. $21^{\mathrm{a}}$ ed. Rio de Janeiro: Forense, 2013. p. 75. Observamos que o autor faz um contraponto entre público e privado que, conforme planejamos expor no decorrer de nosso trabalho, não é aplicável no atual estágio da economia capitalista, tendo em vista que não há uma divisão entre ambos mas sim uma associação para beneficiar-se das riquezas produzidas em comum.
} 
A propriedade não é um instituto de fácil definição, conforme observado em doutrina ${ }^{3}$, tendo em vista seu caráter maleável às particularidades culturais e temporais de diferentes povos. Pretendemos aqui explorar a propriedade como uma série de relações entre pessoas e coisas, conforme estabelece J. Martin Pedersen em seu artigo Properties of Property: A Jurisprudencial Analysis, ao se referir aos "property protocols":

"property is normative protocols structuring social relations with regard to things (that is, property relations) (...) Property protocols refer to customs, norms and conventions guiding people's behavior ${ }^{4}$.

Considerando que o capitalismo tornou-se o sistema hegemônico no mundo ${ }^{5}$, devemos começar nossa análise da propriedade observando como se dão as relações entre coisas e pessoas dentro deste sistema ou, pondo de outra forma, verificar como funcionam os property protocols que operam no capitalismo.

Para isso, pretendemos estudar a abordagem feita pela escola da análise econômica do direito. Fundada por Robert Coase em seu artigo "The Problem of Social Cost" (1961), essa escola defende que os impulsos

\footnotetext{
${ }^{3}$ GROSSI, por exemplo, em seu História da Propriedade e Outros Ensaios (2006), refere-se a ela como "Um instituto, em suma, do qual se deve sublinhar a relatividade"; enquanto que Caio Mário, em obra já citada, diz que "Não existe um conceito inflexível do direito de propriedade. Muito errado o profissional que põe os olhos no direito positivo e supõe que os lineamentos legais do instituto constituem a cristalização dos princípios em termos permanentes, ou que o estágio atual da proprieadade é a derradeira, definitiva fase de seu desenvolvimento. Ao revés, evolve sempre, modifica-se ao sabor das injunções econômicas, políticas, sociais e religiosas." (grifo nosso).

PEREIRA, Caio Mário da Silva. Instituições de Direito Civil. Direitos Reais IV. $21^{\text {a }}$ ed. Rio de Janeiro: Forense, 2013, p. 67.

${ }^{4}$ A propriedade é composta por protocolos normativos que estruturam relações sociais pertinentes às coisas (ou seja, relações de propriedade) (...) protocolos de propriedade referem-se aos costumes, normas e convenções guaindo o comportamento das pessoas."

PEDERSEN, J. Martin; Properties of property: a jurisprudencial analysis. The Commoner, $n^{\circ} 14$, inverno de 2010. Disponível em: <https://commoning.files.wordpress.com/2010/12/thecommoner-14-winter-2010-chapter2.pdf $>$. Acesso em: 05 out. 2016.

${ }^{5} \mathrm{Ou}$, como coloca Fábio Konder Komparato: "Chegamos finalmente, neste vigésimo primeiro século da era cristã, a uma etapa histórica em que todos os povos da Terra, em maior ou menor grau, participam da mesma civilização: a capitalista".

KONDER, Komparato. Capitalismo e Poder. In: WU, Vinicius (org.). Redes, Poder e Democracia no século XXI. Porto Alegre: Sapiens, 2013. p. 17.
} 
econômicos que orientam, de fato, as ações dos indivíduos e se sobrepõem às escolhas determinadas pela lei.

Em seu artigo, Coase parte da análise de casos de Responsabilidade Civil para concluir que, dada a natureza dos custos para a reparação civil dos danos, seria correto inferir que as partes tenderão, observando um padrão de comportamento racional, a buscar sempre uma forma de comporem suas disputas que maximize os ganhos de cada um.

Essa lógica pode ser, como de fato foi, expandida para diferentes áreas do direito, inclusive os direitos reais. Com efeito, para Mackay e Rousseau, a propriedade privada nada mais é do que uma forma de gestão de escassez de bens.

O sistema seus fundamentos estruturais a exclusividade sobre o bem a ser gerido, a garantia de uso (usus) e fruição (fructus) do bem a ser gerido e por fim a do "abuso" (abusus), que seria a prerrogativa do proprietário de transferir o bem para quem desejar.

A questão da exclusividade é fundamental para o raciocínio proposto por essa escola, uma vez que, conforme apontamos, ela parte do pressuposto que os seres humanos agem com base em interesses e, caso um bem fosse de livre acesso, haveria um super consumo do mesmo ${ }^{6}$, o que geraria a sua extinção. Desta forma, a propriedade privada se torna necessária como garantia da melhor manutenção da propriedade pelos mais aptos a fazê-lo.

Trata-se de um sistema que pressupõe, portanto, a abertura total da gestão dos bens voltada para a persecução de fins que beneficiem ao máximo o dono da propriedade gerando, como diz Petersen, "little kings of

\footnotetext{
6 Segundo os autores: "em um cenário de livre acesso a um determinado bem "cada um maximizará o proveito que puder obter pessoalmente sem considerar as consequências para a preservação do recurso: ruína coletiva". MACKAAY, Ejan; ROUSSEAU, Stéphane. Análise econômica do direito. SZTAJN, Rachel (trad.). $2^{\mathrm{a}}$ ed. São Paulo: Atlas, 2015.
} 
property", ou seja, proprietários com totais poderes para fazerem o que quiserem com seus bens ${ }^{7}$.

Por estar inserido dentro deste paradigma, é seguro afirmar portanto, que o sistema jurídico brasileiro objetiva proteger o direito à propriedade privada sem, contanto, regulá-lo em medida que seja além daquela estritamente necessária. Com efeito, no artigo 5 da Constituição Federal lemos as seguintes disposições:

Art. $5^{\circ}$ Todos são iguais perante a lei, sem distinção de qualquer natureza, garantindo-se aos brasileiros e aos estrangeiros residentes no País a inviolabilidade do direito à vida, à liberdade, à igualdade, à segurança e à propriedade, nos termos seguintes:

XXII - é garantido o direito de propriedade;

XXIII - a propriedade atenderá a sua função social;

A Constituição, nesta disposição não define a propriedade, limitando-se a dar-lhe peso principiológico, deixando os seus limites para o legislador, deixando como marco referencial apenas a sua função social.

O dogma da função social da propriedade tornou-se conhecido através do artigo 153, alínea 2, da Constituição de Weimar, que dizia: "a propriedade obriga". A partir de sua redação, podemos entender que há um conjunto de deveres correlatos à detenção da propriedade, do proprietário em relação aos demais membros da sociedade. Como diz Pietro Perlingieri:

Em um sistema inspirado na solidariedade política, econômica e social e ao pleno desenvolvimento da pessoa (art. 2 da Const.) ${ }^{8}$ o conteúdo da função social

\footnotetext{
${ }^{7}$ Observamos que esta concepção de propriedade como elemento regulador de escassez está no cerne de várias críticas aos bens comuns (e ao comum) dentre as quais a formulada por Hardin no seu artigo The Tragedy of Commons (1968). Observamos que os riscos supostamente apresentados por estas duas categorias já foram rebatidos em outras ocasiões, como na obra Governing The Commons, de Elinor Olstrom.

${ }^{8}$ Trata-se do artigo $2^{\circ}$ da Constituição Italiana. No caso do Brasil, poderíamos utilizar como base constitucional para conformar o princípio da função social da propriedade aqueles contidos no artigo $3^{\circ}$ da nossa Carta Magna: (i) constituição de uma sociedade livre, justa e solidária; (ii) garantia do desenvolvimento nacional; (iii) erradicação da pobreza e marginalização, com a redução das desigualdades sociais e regionais e, por fim, (iv) a promoção do bem de todos, sem preconceito de raça, sexo, cor, idade e quaisquer outras formas de discriminação. Como se vê tem-
} 
assume um papel de tipo promocional, no sentido de que a disciplina das formas da propriedade e as suas interpretações deveriam ser atuadas para garantir e para promover os valores sobre os quais se funda o ordenamento ${ }^{9}$.

Considerando a natureza de nosso estudo, não poderíamos deixar de fazer uma pequena crítica ao princípio da função social da propriedade: embora não deixemos de reconhecer a sua importância, ressaltamos que se trata de conceito insuficiente, uma vez que ele apenas relativiza a figura da propriedade, sem retirá-la de seu local sagrado no centro do ordenamento jurídico.

O Código Civil também não apresenta uma definição de propriedade latu sensu, adotando para estes fins a descrição dos direitos dos proprietários, conforme se vê na dicção do artigo 1228 do Código Civil:

Art. 1228: O proprietário tem a faculdade de usar, gozar e dispor da coisa, e o direito de reavê-la do poder de quem quer que injustamente a possua ou detenha.

Vemos, portanto, a presença de uma definição de propriedade aberta, que se define mais enquanto um feixe de direitos ou atribuições de seus proprietários do que como um direito por si só ${ }^{10}$.

Tendo encerrado nossas colocações acerca do instituto da propriedade, exploraremos agora os conceitos de Bens Comuns e Comum, na respectiva ordem.

\subsection{Bens Comuns e o Comum}

Para compreender o conceito de bens comuns, precisaremos antes entender o conceito de bens, em especial à luz do direito brasileiro e com

\footnotetext{
se um rol que, apesar de extenso, é muito aberto às interpretações do aplicador da lei, o que torna a função social da propriedade um princípio de difícil aplicação.

${ }^{9}$ PERLINGIERI, Pietro. Perfis do Direito Civil: Introdução ao Direito Civil Constitucional. Maria Cristina de Cicco (Trad.). $3^{\mathrm{a}}$ ed. Renovar, 2007. p. 226.

${ }^{10}$ É certeiro Hely Lopes Meirelles ao afirmar que o "nosso Código Civil, seguindo a tradição romana, fornece os elementos do direito de propriedade (...) Este direito de uso, gozo e disponibilidade das coisas, associado ao poder de reivindicá-las de quem as detenha injustamente, configura a propriedade, na sua acepção mais ampla".

MEIRELLES, Hely Lopes. Direito de Construir, Malheiros. 10a ed., São Paulo. 2011. p. 19.
} 
pequenas comparações com o direito italiano, uma vez que o conceito de bens comuns que utilizamos se originou neste país.

Primeiramente, ressaltamos que o Código Civil Brasileiro, ao contrário de outras codificações, não apresenta uma definição de bem, tampouco o diferencia do conceito de "coisas"11. Ficou a cargo da doutrina, portanto, no vácuo do legislador, de encontrar uma definição para este conceito, o que foi feito conforme vemos abaixo:

\section{Para Caio Mário:}

São bens jurídicos, antes de tudo, os de natureza patrimonial. Tudo que pode integrar nosso patrimônio é um bem e é um objeto de direito subjetivo. São os bens econômicos. Mas não somente estes são objeto de direito (...) são objeto dos direitos os bens jurídicos, empregamos a expressão em sentido amplo ou genérico, para compreender tudo que pode ser objeto da relação jurídica sem distinção da materialidade ou patrimonialidade. (grifo nosso) ${ }^{12}$.

Daí podemos inferir que o conceito de bens no direito brasileiro é bastante amplo, abarcando tudo o que figurar no polo objetivo de uma relação jurídica. Esta definição está em consonância com o que dizia Clóvis Bevilácqua, conforme citação colhida por Guilherme Couto de Castro: "bens são os valores materiais ou imateriais, que servem de objeto a uma relação jurídica"13.

O ordenamento jurídico italiano, por sua vez, apresenta definição uma definição de bens em seu artigo 810, que possui a seguinte redação:

\footnotetext{
${ }^{11} \mathrm{O}$ conceito de coisas não é alvo do nosso trabalho e não será, portanto, desenvolvido aqui. Entretanto, apenas para dar uma pequena contextualização ao leitor, observamos que as coisas são definidas pela doutrina majoritária como objetos corpóreos, ou seja, não imateriais e que não são objetos de relações jurídicas. Para mais informações acerca desse conceito, recomendamos a leitura do primeiro volume das Instituições de Direito Civil do professor Caio Mário da Silva Pereira, a partir da página 335.

PEREIRA, Caio Mário da Silva. Instituições de Direito Civil. Introdução ao Direito Civil - Teoria geral de Direito Civil V.I. $25^{\mathrm{a}}$ ed. Rio de Janeiro: Forense, 2012. p. 335.

12 PEREIRA, Caio Mário da Silva. Instituições de Direito Civil. Introdução ao Direito Civil Teoria geral de Direito Civil V.I. $25^{\mathrm{a}}$ ed. Rio de Janeiro: Forense, 2012, p. 335.

${ }^{13}$ COUTO DE CASTRO, Guilherme. Direito Civil: Lições. $5^{\mathrm{a}}$ ed. Niterói: Impetus, 2012. p. 28.
} 
"sono bene le cose che possono formare oggeto di diritti" "14 Sobre este dispositivo, afirma Perlingieri que:

"La definizione di bene, contenuta nell'art. 810, fa riferimento a 'diritti'. Il termino 'diritto' però va inteso non in senso stretto, come 'diritto soggetivo', ma come situazione soggetiva, si che la disposizione ca letta in tal senso: sono bene le cose che possono formare oggetto di situazione soggettive e quindi di un rapporto ${ }^{15}$.

Como observamos, no direito italiano, e aí ele se encontra em acordo com o nosso, os bens são o ponto de referência objetivo de qualquer relação jurídica que venha a ser formada - motivo pelo qual eles abrangem mais do que apenas objetos, incluindo até mesmo bens imateriais.

Ademais, no direito brasileiro, os bens são divididos entre públicos e privados conforme a sua titularidade. São públicos os bens pertencentes ao Estado, suas autarquias e fundações, dentre outras ${ }^{16}$. Já os bens privados são aqueles pertencentes à pessoas físicas e também à pessoas jurídicas cuja natureza seja de direito privado.

Trata-se de uma forma tradicional de se dividirem os bens e que é contestada pelo ressurgimento ${ }^{17}$ do conceito de bens comuns, que se opõe a essa divisão tradicional da propriedade. Com efeito, o relatório da Comissão Rodotà para a Reforma das Normas do Código Civil em Matéria de Bens Públicos (doravante chamada apenas de "Comissão Rodotà"), em seu relatório final, afirma que:

\footnotetext{
14 "São bens as coisas que podem formar objetos de direito", tradução nossa.

${ }^{15}$ A definição de bem, contida no artigo 810, faz referência a 'direitos'. O termo 'direito', porém, não deve ser entendido em sentido estrito, como em 'direito subjetivo, mas como situação subjetiva, sendo a disposição lida neste sentido: são bens as coisas que possam figurar como objeto de situações subjetivas e, portanto, de uma relação".

PERLINGIERI, Pietro. Manuele di Diritto Civile. $6^{\text {a }}$ ed. Napoli. Edizioni Scientifiche Italiani. 2007, p. 169.

${ }^{16}$ MELLO, Celso Antônio Bandeira de. Curso de Direito Administrativo. $30^{\mathrm{a}}$ ed. São Paulo: Malheiros, 2012. p. 929.

${ }^{17}$ Conforme trataremos de forma mais detalhada a frente, a Comissão Rodotà foi instalada na Itália para tratar da inclusão, dentre outras coisas, dos bens comuns no direito italiano. Ela foi presidida por Stefano Rodotà, autor de "Il terrible diritto: Studi sulla proprietà privata e i beni comune", uma das obras de referência no estudo dos bens comuns.
} 
Si è prevista, anzitutto, una nuova fondamentale categoria, quella dei beni comuni, che non rientrano stricto sensu nella specie dei beni pubblici, poiché sono a titolarità diffusa, potendo appartenere non solo a persone pubbliche, ma anche a privati ${ }^{18}$.

Ainda segundo o relatório, a titularidade não é o elemento a ser considerado para que um bem seja definido como comum, mas sim a sua utilidade funcional para o exercício de direitos e garantias fundamentais ${ }^{19} \mathrm{e}$ que, portanto, fazem jus a uma tutela diferenciada por parte do ordenamento jurídico $^{20}$.

Trata-se, portanto, de um conceito que ultrapassa a (falsa) dicotomia entre público e privado, buscando uma nova alternativa por fora das duas que são tradicionalmente colocadas. Aqui, observamos que há um reflexo político das escolhas feitas pelos sistemas jurídicos e na sua forma de gerenciamento dos direitos de propriedade - no capitalismo predominando a propriedade privada e no socialismo predominando a propriedade estatal.

Para utilizar as palavras de Antonio Negri e Michael Hardt:

L'alternativa tra pubblico e privato è simetrica all'alternativa, altretanto politicamente perniciosa, tra capitalismo e socialismo. Se dice spesso che l'unica cura per i mali della società capitalistica sia la regolazione pubblica e un governo dell'economia di tipo keynesiano e/o socialista mentre, allo stesso modo, i mali del socialismo possono essere curati soltanto dalla proprietá privata e dal

\footnotetext{
18 "Foi prevista, além de tudo, uma nova categoria fundamental, aquela dos bens comuns, que não bens públicos strictu sensu, uma vez que são de titularidade difusa, podendo pertencer não somente à pessoas públicas, mas a privadas também."

MINISTERO DELLA GIUSTIZIA. Relatório sobre a Comissão Rodotà para reforma das normas do Código Civil em matéria de bens públicos. 14 jun. 2007. Disponível em:

http://www.giustizia.it/giustizia/it/mg 112 1.wp?previsiousPage=mg 11 12\&contentId=SPS 47617, acessado em 29/10/2016.

19 Conforme consta do relatório, são bens comuns "ossia dele cose che esprimono utilitá funzionali all'ezercizio dei diritti fondamentali nonché al libero sviluppo della persona. I beni comuni devono essere tutelati e salvaguardati dall'ordinamento giuridico, anche a beneficio delle generazioni future." ("todas as coisas que exprimem utilidade funcional ao exercício dos direitos fundameitais e ao livre desenvolvimento da pessoa. Os bens comuns devem ser tutelados e salvaguardados pelo ordenamento jurídico também a benefício das gerações futuras.")

MINISTERO DELLA GIUSTIZIA. Relatório sobre a Comissão Rodotà para reforma das normas do Código Civil em matéria de bens públicos. 14 jun. 2007. Disponível em:

http://www.giustizia.it/giustizia/it/mg 112 1.wp?previsiousPage=mg 1 12\&contentId=SPS 47617, acessado em 29/10/2016.

${ }^{20}$ A preocupação com a escassez dos bens comuns e com as gerações futuras está presente nos trabalhos da Comissão Rodotà, bem como no de autores que os estudam, como Ugo Mattei e Stefano Rodotà.
} 
controllo capitalistico. Il socialismo e il capitalismo, che talvolta si sono amalgamti e altre volte sono asperamente combattuti, sono entrambi dei regimi della proprietà che escludono il comune ${ }^{21}$.

Tem-se daí, portanto, que público e privado são "dois lados da mesma moeda", tendo em vista que ambos os sistemas baseiam-se na expropriação e no uso da riqueza comum - com efeito, os autores citados chegam a sustentar não mais haver diferença entre público e privado, existindo apenas uma cooperação entre ambas as esferas voltadas para apropriar-se da riqueza comum, idéia que será retomada mais adiante.

Antes, todavia, precisamos entender melhor o que são os bens comuns, motivo pelo qual nos voltamos para a gênese de seu conceito. Embora se possam apontar outras sociedades que utilizaram formas de "propriedade coletiva", vamos limitar nossa análise ao desenvolvimento dado ao tema a partir do direito romano, uma vez que foi este que mais influenciou as concepções trabalhadas na Comissão Rodotà.

Por fim, alertamos que não faremos uma análise histórica aprofundada dos bens comuns, uma vez que esta demandaria uma profundidade e uma complexidade que não são comportadas por este trabalho, mas apenas faremos observações pontuais de forma a construir melhor nossa tese.

Como aponta Paolo Maddalena em seu artigo "I beni comuni nel codice civile, nella tradizione romanistica e nella Costituzione della Republica Italiana", os bens comuns tem origem no conceito de res

\footnotetext{
21 "A alternativa entre público e privado é simétrica à alternativa, entretanto politicamente capiciosa, entre capitalismo e socialismo. Se diz com frequência que a única cura para os males da sociedade capitalista é a regulação pública e um governo de economia do tipo keynesiano e/ou socialista enquanto, da mesma forma, os males do socialismo podem ser curados somente através da propriedade privada e do controle capitalista. O socialismo e o capitalismo, que volta e meia são mesclados e volta e meia asperamente combatidos, são ambos regimes de propriedade que excluem o comum." (grifo nosso).

HARDT, Michael. NEGRI, Antonio. Comune: oltre il privato e il publico. Alessandro Pandolf (trad.). $1^{\text {a }}$ ed. Milano: Rizzoli Libri, 2010. p. 9.
} 
nullius $^{22}$. Em tradução literal, estas seriam chamadas de coisas nulas, por não possuírem dono. Por este motivo, como diz Maddalena:

Le res nullius sono appropriabili da parte degli individui, non nella loro totalitá, ma nelle singoli parti individuali che le compongono, le quali, sfuggendo al singolo, possono rientrare nella totalità e divenire di nuovo appropriabili da parte di qualsiasi soggetto ${ }^{23}$.

Observamos aqui a notável preocupação dos romanos com a preservação da res nullius para uso futuro por parte de outras pessoas e da coletividade dos seres humanos. Com efeito, a res nullius apenas poderia ser apropriada na medida em que satisfizesse as necessidades daquele responsável pela apropriação e, uma vez satisfeito, este possuía a incumbência de restaurá-la a seu estado original.

Ademais, outro fator importante na formulação deste conceito, como coloca Maddalena, foi a inexistência da personalidade jurídica no direito romano. Antes de adentrarmos mais a fundo neste ponto, todavia, cumpre esclarecer que na maioria dos ordenamentos jurídicos modernos, entidades coletivas não são dotadas, per se, de personalidade e portanto, não poderiam ser sujeito nem objeto de direitos.

Para suprir esta lacuna, foi criada a ficção da personalidade jurídica. Estas entidades, como empresas, fundações e associações, embora não sejam dotadas de personalidade jurídica, são equiparadas a sujeitos de direito e passam, por tanto, a poder atuar como se fossem pessoas perante o direito.

\footnotetext{
${ }^{22}$ É interessante observar que, apesar do direito brasileiro não possuir a categoria dos bens comuns, Caio Mário, a partir do conceito de res nullius, faz referência à "coisa comum" que "podem ser utilizadas por qualquer pessoa, embora não dominadas (...) a coisa sem dono - res nullius - não pertence a quem quer que seja, mas acha-se à disposição do primeiro que a tomar." Trata-se de conceito que, apesar de interessante, é obviamente mais limitado que o dos bens comuns por não poder formar uma relação jurídica.

23 “A res nullius é apropriável da parte dos indíviduos, não na sua totalidade, mas em partes singulares e individuais que a compõe as quais, destacando-se do singular, podem reentrar na totalidade e tornar-se novamente apropriáveis da parte de qualquer sujeito".

MADDALENA, Paolo. I beni comuni nel codice civile, nella tradizione romanistica e nella Costituzione della Repubblica italiana, disponível em. Disponível em: <http://www.eurasiarivista.org/i-beni-comuni-nel-codice-civile-nella-tradizione-romanistica-e-nella-costituzione-dellarepubblica-italiana/11508/>. Acesso em: 12 nov. 2016.
} 
Para ilustrar o conceito acima exposto, trazemos citação do professor Caio Mário, que dizia que "nem se poderá objetar que esta personalidade e esta capacidade são fictícias em razão de provirem da lei",24. Trata-se, portanto, de determinação do ordenamento jurídico feita apenas para facilitar os trâmites comerciais, a gestão da propriedade etc.

Já no direito romano, as coletividades eram entendidas como dotadas de personalidade per se e portanto poderiam ser sujeitos de direito, conforme explica Maddalena:

É qui è da sottolineare che, a differenza dei moderni, per i quali i soggeto è sempre una individualità (persona fisica) e, quando si vuol riconosecere la soggettività ad un soggeto plurimo o ad una colletività, si recorre al concetto, acnh'esso individualistico, di persona giuridica (...) presso i Romani non se esitava a riconoscere la soggetività giuridica agli enti piu diversi ${ }^{25}$.

O jurista italiano prossegue discorrendo sobre os diferentes tipos de propriedade coletiva dentro do direito romano, como por exemplo, a res sacrae, de propriedade dos templos mas também disponível para o uso dos seus fiéis. O mais importante, entretanto, é frisar que a própria coletividade dos seres humanos gozava de personalidade e, portanto, poderia ser sujeito de direitos, inclusive direitos de propriedade.

A partir daí, Maddalena conclui por existir, no direito romano, uma previsão expressa de bens que são inteiramente pertencentes, por sua natureza, à toda coletividade e que também poderiam, por isso, ser entendidos como bens comuns: "L'insegnamento delle fonti romane ̀̀ davvero eccezionale: non solo ci sono i beni del populus, del Municipio o delle Coloniae, ma ci sono anche $i$ beni dell'intera comunità degli

\footnotetext{
${ }^{24}$ PEREIRA, Caio Mário da Silva. Instituições de Direito Civil. Introdução ao Direito Civil Teoria geral de Direito Civil V.I. $25^{\mathrm{a}}$ ed. Rio de Janeiro: Forense, 2012. p. 257.

25 "É necessário sublinhar aqui que, diferentemente dos modernos, para os quais o sujeito é sempre uma individualidade (pessoa física) e, quando se quer reconhecer a subjetividade de um sujeito plural ou de uma coletividade, se recorre ao conceito, também individualista, de pessoa jurídica (...) para os romanos não havia hesitação em reconhecer a subjetividade jurídica aos entes mais diversos".

MADDALENA, Paolo. I beni comuni nel codice civile, nella tradizione romanistica e nella Costituzione della Repubblica italiana, disponivel em. Disponível em: <http://www.eurasiarivista.org/i-beni-comuni-nel-codice-civile-nella-tradizione-romanistica-e-nella-costituzione-dellarepubblica-italiana/11508/>. Acesso em: 12 nov. 2016.
} 
uomini ${ }^{, 26}$. Dentre esses bens Maddalena cita o ar, a água corrente, o mar e seu leito, animais silvestre, peixes dentre outros. Todos, conforme destaca o jurista, bens da coletividade e que por ela devem ser livremente gozados, respeitando-se o limite imposto pelas necessidades dos seus demais membros.

Trata-se, como se vê, de um conceito jurídico com sólido fundamento no direito romano. Não apenas isto, mas ele continuou se propagando pelo medievo até o início das colonizações. O motivo da interrupção, ou desaparecimento, dos bens comuns será objeto da próxima etapa da nossa análise.

Como se sabe, o marco histórico inicial da Idade Média é a queda do Império Romano, que ocorreu no ano de 476 d.C. Como ressalta Mattei ${ }^{27}$, o processo de transição histórica entre as duas etapas se deu de forma lenta, possibilitando a manutenção de algumas das estruturas presentes na sociedade e no direito romano como, por exemplo, o da propriedade comum.

Mattei estabelece algumas bases para que este processo possa acontecer. O primeiro poderia ser considerado uma "difusão de poderes" no medievo, no qual diversas instituições operavam de formas diferentes, muitas vezes no mesmo território, com normas vinculando apenas aqueles a elas filiados. Desta forma, o direito mercantil governava os mercadores, o direito canônico os cléricos e assim por diante ${ }^{28}$.

Para Mattei, a resultante disso seria uma série de lutas políticas que, entretanto, não alterariam a vida quotidiana das pessoas comuns, uma vez

\footnotetext{
26 "O ensinamento das fontes romanas é verdadeiramente excepcional: não só existem os bens do povo, do Município ou das Colônias, mas existem também os bens de toda a comunidade dos homens".

MADDALENA, Paolo. I beni comuni nel codice civile, nella tradizione romanistica e nella Costituzione della Repubblica italiana, disponivel em. Disponível em: <http://www.eurasiarivista.org/i-beni-comuni-nel-codice-civile-nella-tradizione-romanistica-e-nella-costituzione-dellarepubblica-italiana/11508/>. Acesso em: 12 nov. 2016.

${ }^{27}$ MATTEI, Ugo. Beni comuni: un manifesto. $1^{\text {a }}$ ed. Roma-Bari: Editora Laterza \& Figli Spa, 2012. p. 26.

${ }^{28}$ MATTEI, Ugo. Beni comuni: un manifesto. $1^{\mathrm{a}}$ ed. Roma-Bari: Editora Laterza \& Figli Spa, 2012 p. 25.
} 
que esta seria mais baseada no status. Isso ocorreria porque, como diz Mattei, a maior parte dessas populações vivia a margem dessas lutas e com poucos recursos, o que geraria uma economia de subsistência baseada na solidariedade de seus membros ${ }^{29}$.

Este sistema teria se intensificado, conforme fala Mattei, pelo colapso gradual da infra-estrutura do Império Romano, tornando as viagens mais difíceis e perigosas, reforçando, portanto, o isolamento destas comunidades, tornando mais fortes os laços que uniam os moradores dessas comunidades, baseados em uma experiência de vida em comum ${ }^{30}$.

Para Mattei, o comum no medievo abarcava, dentre outros, os bosques, onde abundava a caça e colhia-se a lenha; rios e torrentes, de onde se retiravam as águas e que podiam também ser utilizados para o transporte e até mesmo as cidades, nas quais encontrava-se não só a proteção das muralhas como também uma série de outros lugares comuns nos quais se organizava a vida social ${ }^{31}$.

Embora se trate de conceito certamente conhecido das sociedades ocidentais - e de seu direito, tendo em vista sua origem ainda na época do império romano - ele acabou por desaparecer no decurso do processo histórico com ascensão do sistema capitalista. Com efeito, vários autores ${ }^{32}$

\footnotetext{
29 "La maggior parte della popolazione europea viveva con poche risorse nelle campagne, dedita a un'economia di sostentamento, il cui motore era la solidarietà del gruppo". (A maior parte da população européia vivia com poucos recursos nos campos, dedicados a uma economia de autossustentação, cujo motor era a solidariedade do grupo.”).

MATTEI, Ugo. Beni comuni: un manifesto. $1^{\mathrm{a}}$ ed. Roma-Bari: Editora Laterza \& Figli Spa, 2012, p. 26.

30 "L'avere in comune non era distinguibile dall'essere in comune, e certamente l'avere individuale de risorse significative costituiva un eccezione, riservata a pocchi e sconosciuta di piu" ("O ter em comum não era distinguível do ser em comum e, certamente, o ter individual de recursos constituia uma exceção, reservada a poucos e desconhecida da maioria”). Mattei não é o único a apontar uma incompatibilidade entre a filosofia individualista, típica do capitalismo, e os comuns (cf. Nota 32).dsa

MATTEI, Ugo. Beni comuni: un manifesto. $1^{\text {a }}$ ed. Roma-Bari: Editora Laterza \& Figli Spa, 2012, p. 26.

31 MATTEI, Ugo. Beni comuni: un manifesto. $1^{\text {a }}$ ed. Roma-Bari: Editora Laterza \& Figli Spa, 2012 p. 27.

${ }^{32}$ Conferir também, nesse sentido, Grossi; Rodotà; Lucarelli e Hardt e Negri. Por todos, citamos o professor Fábio Konder Komparato, quando diz que: "O capitalismo, contrapondo-se ao ideal republicano, fez desaparecer, de certa forma, a velha noção de bem comum ou comunidade. $\underline{\mathrm{O}}$ adjetivo próprio é antônimo de comum".
} 
já identificaram uma incompatibilidade, em algum grau, com o capitalismo e os comuns.

Isso se dá porque, conforme esclarecem Mattei e Nader em sua obra "Pilhagem: quando o Estado de Direito é ilegal", o sistema capitalista tem a sua base na apropriação (a qual os autores chamam de pilhagem) da riqueza comum e a sua conversão em uma riqueza individual. Portanto, com a ascensão do capitalismo, as categorias de bens comuns foram rapidamente desaparecendo. Antes de prosseguirmos com nossa análise, precisamos apresentar, dada a sua importância, a definição que Mattei e Nader dão para "pilhagem":

O American Heritage Dictionary define o verbo pilhar (plunder) como 'roubar bem alheio por meio da força, principalmente em tempos de guerra; saquear' e o substantivo pilhagem como 'propriedade roubada por meio de fraude ou força.' É esta última definição que nos traz à mente, de modo especial, o lado obscuro do Estado de Direito ${ }^{33}$

No decorrer da História, observamos o surgimento de uma forma de organização estatal cujas bases são a pilhagem do comum para o benefício de uma elite limitada. O Capital, da forma como o conhecemos hoje, não poderia ter ascendido sem a presença deste "motor", cuja primeira expressão foi no movimento colonialista ${ }^{34}$ promovido pelas potências européias. A ascensão capitalista não teria sido possível sem a pilhagem ${ }^{35}$.

KONDER, Komparato. Capitalismo e Poder. In: WU, Vinicius (org.). Redes, Poder e Democracia no século XXI. Porto Alegre: Sapiens, 2013. p. 37

${ }^{33}$ MATTEI, Ugo; NADER, Laura. Pilhagem: Quando o Estado de Direito é ilegal. CAMARGO, Jefferson Luiz (Trad.). $1^{\text {a }}$ ed. São Paulo: Martins Fontes, 2013. p. 17.

${ }^{34}$ (...) la modernità è una relazione di potere tra dominio e resistenza, tra sovranità e lotte di liberazione (...) Il colonialismo è costitutivo della modernità nella misura in cui detta i termini delle gerachie al cuore stesso della modernità." ( A modernidade é uma relação de poder entre domínio e resistência, entre soberania e lutas de liberação (...) o colonialismo é constitutivo da modernidade na medida em que dita os termos das hierarquias presentes no coração da modernidade".

HARDT, Michael; NEGRI, Antonio. Comune: oltre il privato e il publico. Alessandro Pandolf (trad.). $1^{\text {a }}$ ed. Milano: Rizzoli Libri, 2010., 2010, p. 75.

35 "Por trás das primeiras tentativas coloniais das potências europeias encontra-se a urgência de financiar a imensa necessidade econômica dos novos sistemas centralizados de governo, essenciais para o desenvolvimento capitalista. Sem ouro, prata, algodão e seres humanos provenientes de terras distantes, teria sido impossível financiar o sistema institucional que prepararia o caminho da industrialização e do desenvolvimento". 
Ao longo das três revoluções burguesas - a inglesa, a americana e a francesa - testemunhamos o surgimento daquilo que Hardt e Negri chamam de "republica della proprietà", ou república da propriedade, que consiste na "creazione di un ordine costituzionale e dello Stato di diritto ha avvuto lo scoppo di difendere e legittimare la proprietà privata",36.

Para os fins do nosso presente trabalho, pretendemos focar no desenvolvimento do direito de propriedade durante o curso da Revolução Francesa, por entendermos que ali começou o processo histórico que culminou com a promulgação do Código Civil Napoleônico, que consagrou em seu artigo 554 os ideais de absolutismo proprietário que até hoje ressoam nos ordenamentos jurídicos modernos ${ }^{37}$.

Para Hardt e Negri, o processo ocorrido na Revolução Francesa foi o mais agressivo de todos. Com efeito, os autores promoveram um levantamento nas três constituições $(1789,1793$ e 1795) e constataram que, embora em todos ela possua a mesma definição, há uma mudança no entendimento que se tem entre propriedade e igualdade a partir da Constituição de 1795, que se opera da seguinte forma: "mentre nel 1789 e nel 1793 il diritto di proprietà è collegato con il diritto di 'resistenza

MATTEI, Ugo; NADER, Laura. Pilhagem: Quando o Estado de Direito é ilegal. CAMARGO, Jefferson Luiz (Trad.). $1^{\text {a }}$ ed. São Paulo: Martins Fontes, 2013. p. 35.

Os autores também defendem que o capitalismo nunca foi capaz de romper com a lógica colonialista, mas continuou operando a partir dos mesmos paradigmas.

36 "criação de uma ordem constitucional e de Estado de Direito com a função de defender e legitimar a propriedade privada". Para um estudo mais aprofundado recomendamos a leitura da obra citada de Hardt e Negri, cuja versão em português foi recentemente lançada com o título de "Bem Estar Comum".

HARDT, Michael; NEGRI, Antonio. Comune: oltre il privato e il publico. Alessandro Pandolf (trad.). $1^{\text {a }}$ ed. Milano: Rizzoli Libri, 2010, p. 23.

${ }^{37}$ Como diz Rodotà na introdução de seu "Terrible Diritto", a propriedade parece ter retornado a ocupar um lugar de primazia no Direito: "Quel che non si poteva gia allora prevedere, invece, era l'accelerazione che saerbbe stata impressa a quella tendenza da una serie di vicende che, scardinando asstti politici e giuridici, avrebbe davvero dato l'impressione di una proprietà di nuovo collocata 'nell'antico santuario', con una pienezza di prerogative e una legittimazione tanto forti da riproporla, secondo un'antica tradzione, come misura di tutti i raporti economici, sociali, giuridici". ("O que não se podia prever, à época, era a aceleração que foi impressa àquela tendência, por uma série de eventos que, combinando questões políticas e jurídicas, deu a impressão de ter colocado a propriedade novamente em seu 'antigo santuário', repleta de prerrogativas e com forte legitimidade para ser novamente proposta, segundo uma antiga tradição, como a medida de todos os acontecimentos econômicos, sociais e jurídicos".

RODOTÀ, Stefano. Il terribile diritto: Studi sulla proprietà privata e i beni comuni. $3^{\mathrm{a}}$ ed. Bologna: Società editrice il Mulino, 2013. p. 7. 
all'opressione', nel 1795 è tutt'uno con il diritto alla sicureza",38. Trata-se de movimento jurídico que retira qualquer teor porventura revolucionário que a propriedade pudesse vir a possuir.

Ademais, continuando sua análise, os autores constatam que nas constituições de 1789 e 1793 a igualdade era definida como um direito fundamental para tudo e todos, enquanto que na constituição de 1795 ela passa a ser subordinada aos poderes da maioria dos cidadão e dos seus representantes, tornando-se, nas palavras de Hardt e Negri, "una figura giuridica che protegge la ricchezza e che rafforza il potere di appropriazione dell'individuo (inteso come titulare della proprietà privata) ${ }^{, 39}$.

O próximo passo na consolidação da propriedade como o princípio detentor da primazia dentro do ordenamento jurídico foi o artigo 544 do Código Civil de Napoleão, que dizia: “A propriedade é o direito de gozar e dispor da coisa da forma mais absoluta, contanto que não se faça uso proibido pela lei ou por outros regulamentos".

E assim permaneceu a propriedade. Apesar de recentes releituras do conceito, ele nunca deixou de deter, de fato, a primazia no ordenamento jurídico. E é contra isso, conforme veremos adiante, que os bens comuns e também o comum - se insurgem.

Tendo demonstrado a sua origem e o seu desenrolar histórico, chegou a hora de definir - e também diferenciar - os conceitos de bens comuns e de comum. Os bens comuns, conforme já adiantamos, são uma categoria jurídica que abarcam bens que exerçam uma funcionalidade essencial para a preservação e exercício de direitos e garantias

\footnotetext{
38 "Enquanto em 1793 e 1798 o direito à propriedade é correlato ao direito de resistir à opressão, em 1795 ele passa a ser parte do direito à segutança".

HARDT, Michael; NEGRI, Antonio. Comune: oltre il privato e il publico. Alessandro Pandolf (trad.). $1^{\text {a }}$ ed. Milano: Rizzoli Libri, 2010. p. 25.

39 "Uma figura jurídica que protege a riqueza e que reforça o poder de apropriação do indíviduo (entendido como titular da propriedade privada)."

MATTEI, Ugo. Beni comuni: un manifesto. 1ª ed. Roma-Bari: Editora Laterza \& Figli Spa, 2012, p. 25.
} 
fundamentais. Além disso, essa categoria abarca também o patrimônio arquitetônico, cultural e até mesmo os direitos de uma determinada população $^{40}$.

Com efeito o conteúdo comum de um determinado bem também pode ser observado a partir de seu uso, quando dele resulta a atribuição de caracteristícas comuns ou universais, conforme explica Mattei, ao dar o exemplo das praças:

Una piazza non è bene comune in quanto mero spazio fisico urbanistico, ma lo è in quanto luogo di acesso sociale e di scambio esistenziale. Difficile sarebbe separare i tratti fisici da quelli sociali di una piazza e in efetti l'esclusione di determinati gruppi di indivudui dalle panchine o dai tavolini dei bar costituirebbe una violazione del principio fondamentale dell'acesso universale a un bene comune $^{41}$.

Já o conceito de comum é um pouco diferente do de bens comuns, já que ele não depende de um conteúdo jurídico, como a priori aconteceria com os bens comuns, mas é dotado de um viés biopolítico, uma vez que está diretamente ligado à produtividade da multidão, conceito que será melhor esclarecido em nosso próximo capítulo.

Primeiramente, devemos analisar o conteúdo do conceito de bens comuns e, para tal, não podemos nos desviar dos inovadores trabalhos da Comissão Rodotà. Trata-se de uma comissão criada para a elaboração de

\footnotetext{
40 "la stessa idea de legalità puo considerarsi in un certo senso un bene comune. Infatti occorre riconoscere appieno il fatto che il diritto non è una entita oggettiva, meccanica, (cioè una tecnologia); al contrario, esso è un artefatto culturale simile al linguaggio, che prende vita dall'inevitabile interpretazione che ne offre una comunità umana sempre in trasformazione". ("A própria ideia de legalidade pode ser considerada, em certo sentido, um bem comum. Com efeito, devemos reconhecer o fato que o direito não é uma entidade objetiva, mecânica (isto é, uma tecnologia); ao contrário, é um artefato cultural, similar à linguagem, que toma vida a partir das inevitáveis interpretações que lhe são dadas por uma comunidade humana em permanente transformação.”

MATTEI, Ugo. Beni comuni: un manifesto. $1^{\mathrm{a}}$ ed. Roma-Bari: Editora Laterza \& Figli Spa, 2012, p. 58.

41 "uma praça não é um bem comum enquanto mero espaço físico urbanistíco, mas sim enquanto lugar de acesso social e intercâmbio existencial. Difícil seria separar os traços físicos daqueles sociais de uma praça e, com efeito, a exclusão de determinados grupos de indíviduos dos banquinhos ou das mesas dos bares constituiria uma violação do princípio fundamental do acesso universal a um bem comum".

MATTEI, Ugo. Beni comuni: un manifesto. $1^{\text {a }}$ ed. Roma-Bari: Editora Laterza \& Figli Spa, 2012, p. 55.
} 
um projeto de lei delegada visando reformar o capítulo de bens do código civil italiano, tendo como um de seus objetivos a inclusão, no ordenamento jurídico daquele país, de uma regulamentação dos bens comuns.

A Comissão surgiu na esteira dos referendos pela privatização da água na Itália. Com a vitória estrondosa do não, e as mobilizações populares que conduziram a este resultado, ficou patente a obsolescência do código italiano, datado de 1942, motivo pelo qual decidiu-se reformulá-lo, conforme o relatório da Comissão mostra claramente:

Nello svolgimento di tale compito, e alla luce dei primi processi di valorizzazionee privatizziazione di alcuni grupi di cespiti publicci (immobili e crediti) era emersa la necessità di poter contare su un contesto giuridico dei beni che fosse più al passo con i tempi ed in gardo di definire criteri generali e diretive sulla gestione e sulla eventuale dismissione di beni in ecesso delle funzioni pubbliche, e soprattutto sulla possibilità che tali dismissioni (ed eventuali operazioni di vendita e riaffito dei beni) fossero realizzate nell'interesse generelae della collettività facendo salvo un orizzonte di medio e lungo período ${ }^{42}$.

Além da preocupação com a gestão dos bens, havia também uma forte percepção de que os bens comuns, muitos deles escassos, poderiam esgotar-se e que, portanto, deveriam gozar de uma proteção legal mais robusta.

Ao final de seus debates, a Comissão chegou a uma definição de bens comuns e de sua regulamentação jurídica. Apesar de longa, devido a sua importância, a transcreveremos em sua integralidade:

Previsione della categoria dei beni comuni, ossia delle cose che esprimono utilità funzionali all' esercizio dei diritti fondamentali nonché al libero sviluppo della persona. I beni comuni devono essere tutelati e salvaguardati dall'ordinamento

\footnotetext{
42 "No desenvolvimento de tal situação, e a luz dos primeiros processos de valorização e privatização de alguns grupos de ativos públicos (imóveis e créditos) emergiu a necessidade de poder contar, em um contexto jurídico, com bens que fossem mais adequados aos tempos e em posição de definir critérios gerais e diretivos sobre a gestão e eventual descarga de bens em excesso de funções públicas e, sobretudo, sobre a possibilidade que tais descargas (e eventuais operações de venda e recompra dos bens) fossem realizadas no interesse geral da coletividade, visando um horizonte de médio a longo prazo."

MINISTERO DELLA GIUSTIZIA. Relatório sobre a Comissão Rodotà para reforma das normas do Código Civil em matéria de bens públicos. 14 jun. 2007. Disponível em: $<$ http://www.giustizia.it/giustizia/it/mg_1_12_1.wp?previsiousPage=mg_1_12\&contentId=SPS 47617>. Acesso em: dia 22 de setembro de 2016.
} 
giuridico, anche a beneficio delle generazioni future. Titolari di beni comuni possono essere persone giuridiche pubbliche o privati. In ogni caso deve essere garantita la loro fruizione collettiva, nei limiti e secondo le modalità fissati dalla legge. Quando i titolari sono persone giuridiche pubbliche, i beni comuni sono gestiti da soggetti pubblici e sono collocati fuori commercio; ne è consentita la concessione nei soli casi previsti dalla legge e per una durata limitata, senza possibilità di proroghe. Sono beni comuni, tra gli altri: i fiumi, i torrenti e le loro sorgenti; i laghi e le altre acque; l'aria; i parchi come definiti dalla legge, le foreste e le zone boschive; le zone montane di alta quota, i ghiacciai e le nevi perenni; i lidi e i tratti di costa dichiarati riserva ambientale; la fauna selvatica e la flora tutelata; i beni archeologici, culturali, ambientali e le altre zone paesaggistiche tutelate. La disciplina dei beni comuni deve essere coordinata con quella degli usi civici. Alla tutela giurisdizionale dei diritti connessi alla salvaguardia e alla fruizione dei beni comuni ha accesso chiunque. Salvi i casi di legittimazione per la tutela di altri diritti ed interessi, all'esercizio dell'azione di danni arrecati al bene comune è legittimato in via esclusiva lo Stato. Allo Stato spetta pure l'azione per la riversione dei profitti. I presupposti e le modalità di esercizio delle azioni suddette saranno definite dal decreto delegato",43.

\section{Infelizmente, o projeto de lei delegada entregue pela Comissão ainda}

aguarda votação. Não obstante, como frisa Mattei, a elaboração do projeto, por si só, foi um grande triunfo pela forma como foi feita. Conforme ele explica em obra já aqui citada, os andamentos dos trabalhos da Comissão apenas foram possíveis a partir de uma interlocução entre intelectuais e movimentos sociais italianos, que pressionaram sempre pelo prosseguimento do trabalho. Para ele, está aí a semente de uma nova forma de fazer política, com intensa e ativa participação direta da população e

\footnotetext{
43 “Previsão [no Código Civil] da categoria dos bens comuns, composta pelas coisas que exprimem utilidade funcional ao exercício dos direitos fundamentais e ao livre desenvolvimento da pessoa. Os bens comuns devem ser tutelados e salvaguardados pelo ordenamento jurídico, também a benefício das gerações futuras. Titulares dos bens comuns podem ser pessoas jurídicas públicas ou privadas. Em ambos os casos, deve ser garantida a sua fruição coletiva, nos limites e nas modalidades fixadas em lei. Quando os titulares forem pessoas jurídicas públicas, os bens comuns serão geridos por sujeitos públicos e colocados fora do comércio; lhes será permitida a concessão somente nos casos previstos em lei e por uma duração limitada, sem possibilidade de prorrogação. São bens comuns, entre outros, os rios, torrentes e suas fontes; lagos e outras águas; o ar; os parques como definidos em lei, as florestas e bosques; as zonas montanhosas de grande altitude, as geleiras e neves perenes; o leito e áreas costeiras declarados reservas ambientais; a fauna selvagem e a flora tutelada. A disciplina dos bens comuns deve ser coordenada com aquela dos usos civis. A tutela jurisdicional dos direitos conexos à salvaguarda e uso fruto dos bens comuns são responsabilidade de todos/ Salvo os casos de legitimação pela tutela de interesses, o exercício da ação de danos causados aos bens comuns é de legitimidade exclusiva do Estado. Ao Estado cabe também a ação para reverter os lucros. Os pressupostos e modalidades de exercício das ações citadas serão definidos por decreto".

MINISTERO DELLA GIUSTIZIA. Relatório sobre a Comissão Rodotà para reforma das normas do Código Civil em matéria de bens públicos. 14 jun. 2007. Disponível em: $<\mathrm{http} / / /$ www.giustizia.it/giustizia/it/mg_1_12_1.wp?previsiousPage=mg_1_12\&contentId=SPS 47617>. Acesso em: dia 22 de setembro de 2016.
} 
ultrapassando as vias institucionais tradicionais. Para o professor da Universidade de Turim, nisto consiste o maior dos legados da Comissão Rodotà.

O conceito de Comum, por sua vez, guarda muitas semelhanças com o dos bens comuns. Em uma das primeiras definições dadas por Hardt e Negri, inclusive, observamos uma correspondência quase que integral com aquilo que foi estabelecido pela Comissão. Entretanto, há uma diferença fundamental entre os dois conceitos, que é a sua origem. Enquanto os bens comuns possuem seu fundamento e a origem de sua tutela no ordenamento jurídico, os comuns surgem a partir das lutas efetivadas pela multidão através do encontro entre suas singularidades. Desta forma, ele abrange tudo que surge das e é necessário para as interações sociais. Ou, nas palavras de Hardt e Negri:

Per comune si deve intendere, con maggior precisione, tutto ciò che si ricava dalla produzione sociale, che è necessario per l'interazione sociale e per la prosecuzione della produzione, come le conoscenze, i linguaggi, i codici, l'informazione, gli affetti e così via ${ }^{44}$.

Com efeito, logo a seguir os autores dão como exemplo de Comum a linguagem porque, conforme explicado:

Il linguaggio, gli afetti e le espressioni umane sono, per la maggior parte comuni. Se il linguaggio fosse privatizzato, o reso integralmente pubblico - se le parole, le frasi o intere parti de nostri discorsi fossero sottomessi alla proprietà privata $\mathrm{o}$ ai pubblici potere - esso perderebbe la sua espressività, la sua cretività e la capacità di comunicare ${ }^{45}$.

\footnotetext{
44 "Por comum se deve entender, com maior precisão, tudo que é recuperado pela produção social, que é necessário para a interação social e a persecução da produção, como o conhecimento,a linguagem, os códigos, as informações e elementos corretlatos".

HARDT, Michael; NEGRI, Antonio. Comune: oltre il privato e il publico. Alessandro Pandolf (trad.). $1^{\text {a }}$ ed. Milano: Rizzoli Libri, 2010. p. 8.

${ }^{45}$ A linguagem, os afetos e as expressões humanas são, em sua maior parte, comuns. Se a linguagem fosse privatizada, ou tornada integralmente pública - se as palavras, frases ou partes inteiras de nossos discursos fossem submetidas à propriedade privada ou aos poderes públicos essas perderiam sua expressividade, criatividade e capacidade de comunicar".

HARDT, Michael; NEGRI, Antonio. Comune: oltre il privato e il publico. Alessandro Pandolf (trad.). $1^{\text {a }}$ ed. Milano: Rizzoli Libri, 2010. p. 8.
} 
O comum, por tanto, se assemelha mais a uma rede, que está em permanente expansão, por ser aberta às subjetividades de seus usuários. A constituição do comum se renova constantemente porque ele tem a sua base no trabalho e na potência da multidão, que unida através de suas singularidades atua constantemente sobre ele. É por isso que é tão didático o exemplo da linguagem: o comum não só é utilizado constantemente pela multidão como, ao ser afetado pelos usos por ela dados, também sofre modificações.

É, por sua própria natureza, um conceito extremamente complexo e de difícil compreensão. Não conseguiremos entender o comum e a sua expansividade se não entendermos o seu motor, que é a multidão. Para isso, dedicaremos o nosso próximo capítulo. 


\section{CAPÍTULO 2 - 0 PODER CONSTITUINTE E A MULTIDÃo}

\subsection{Modernidade em conflito}

Não se pode compreender a Multidão, em Negri, sem que se compreenda antes o conceito de Poder Constituinte na obra do filósofo italiano, o qual difere radicalmente - ou, poderíamos até dizer, antagoniza com o conceito tradicionalmente adotado pelos juristas em suas obras. Isto ocorre porque, na obra negriana, a potência da multidão, conforme falaremos adiante, está intrinsecamente ligada ao Poder Constituinte.

Negri traça a sua conceituação a partir da análise conjunta de diversos autores e processos históricos em obra chamada "O Poder Constituinte". Partindo de Maquiavel, a quem considera o fundador do conceito, até a Revolução Russa, o autor tira de cada episódio um elemento chave para a definição que dá a este conceito. Nosso objetivo, neste tópico, será o de refazer, de forma sucinta, este processo para entender quais são, na filosofia negriana, os elementos que constituem o Poder Constituinte.

Antes de prosseguirmos neste caminho, entretanto, necessitamos fazer algumas considerações acerca da modernidade dentro da obra de Anotnio Negri. Para o filósofo italiano, no interior da modernidade há um conflito entre imanência e transcendência, que se traduz no conflito entre forças liberatórias e forças reguladoras, que buscam impedir o avanço daquelas. A própria "descoberta", por assim dizer, do plano da imanência foi fundamental para que a Europa entrasse na modernidade ${ }^{46}$. De fato, conforme atesta Guimaraens, "é preciso compreender a fase inicial da modernidade como momento no qual foi determinada uma enorme

\footnotetext{
46 "A afirmação da prática da imanência permitiu que o mundo fosse multiplicado. Homogeneidade e unidade não faziam mais sentido neste novo estado de coisas apresentado. Multiplicidades de singularidades: eis o que se afirma durante o período de fundação da modernidade".

GUIMARAENS, Francisco de; O poder constituinte na perspectiva de Antonio Negri: um convite muito além da modernidade hegemônica. $1^{\mathrm{a}}$ ed. Rio de Janeiro: Editora Forense, 2004. p. 110.
} 
aceleração no tempo, o que resultou na corrosão das bases nas quais se assentava o medievo"

Todavia, conforme prossegue a sua análise, Guimaraens conclui que, embora o plano da imanência tenha sido fundamental para a ruptura das estruturas do medievo, tão logo estas foram rompidas foi imposto um novo projeto de modernidade cuja a base estrutural era a transcendência ${ }^{48}$.

Essa transcendência se traduz na obra de alguns autores como Descartes, para quem o mundo se baseia na dualidade Deus (criador)/ser humano (criatura) ${ }^{49}$, estando o primeiro em um plano (transcendente) inacessível ao segundo de forma direta - posto estar situado em um plano imanente e, mais importante do que Descartes, Hobbes.

Hobbes foi um autor fundamental para o projeto de modernidade baseado na transcendência, uma vez que ele a obra dele funda uma concepção de Estado baseado na figura do soberano, transcendente e onipotente. Para isso, parte de um "estado de natureza" humano como um conflito generalizado entre os indíviduos que, visando encerrá-lo, fazem um pacto entre si e estabelecem que serão governados por um indíviduo que estará acima de todos ${ }^{50}$. Conforme afirmam Hardt e Negri:

Hobbes dichiara che il re è il popolo dato che quest'ultimo, a differenza della moltitudine, è un soggeto unico per cui può essere rappresentato da un'unica persona. In apparenza, questa distinzione è semplicemente geometrica: il popolo è uno (e dunque è capace di

\footnotetext{
47 GUIMARAENS, Francisco de; O poder constituinte na perspectiva de Antonio Negri: um convite muito além da modernidade hegemônica. $1^{\mathrm{a}}$ ed. Rio de Janeiro: Editora Forense, 2004. P 110 .

48 “Como já apreciado anteriormente, é na transcendência que se calca o projeto da modernidade 'vencedora', o que por si só já indica uma contradição interna desta vertente da modernidade: afirmou-se na imanência para derrotar o 'ancién regime', mas se negou a imanência, logo em seguida, para que se instaurasse um regime de constante liberação".

GUIMARAENS, Francisco de; O poder constituinte na perspectiva de Antonio Negri: um convite muito além da modernidade hegemônica. $1^{a}$ ed. Rio de Janeiro: Editora Forense, 2004. P.110.

49 GUIMARAENS, Francisco de; O poder constituinte na perspectiva de Antonio Negri: um convite muito além da modernidade hegemônica. $1^{a}$ ed. Rio de Janeiro: Editora Forense, 2004.p. 110.

50 SILVA, Valeska S. Rodrigues. A Política da Multidão: a Constituição da Democracia do Comum no Pensamento de Antonio Negri. Rio de Janeiro. 2014. (Dissertação de Mestrado) Departamento de Direito da PUC-Rio; Dissertação apresentada no programa de Mestrado em Teoria do Estado e Direito Constitucional da PUC-Rio sob orientação do Prof. Adriano Pilatti em 2014. p. 28.
} 
esercitare la sovranità) mentre la moltitudine è plurale (è incoerente e dunque incapace di autogovernarsi)..$^{51}$

Em Hobbes, o próprio contrato social pode ser entendido como um elemento transcendental, uma vez que é um evento fundador da ordem social, anterior, portanto, ao seu estabelecimento e que a permeia em todas as suas esferas. É por isso que é possível traçar um paralelo entre o seu pensamento e o de filósofos tidos como mais liberais ou democráticos, como Rousseau, que também estabelece no fundamento da ordem social a assinatura de um "contrato", ainda que baseado na soberania e vontade do povo $^{52}$.

Do outro lado, nós temos três autores essenciais na formulação do pensamento imanente que constitui a "modernidade derrotada", por assim dizer: Maquiavel, Spinoza e Marx ${ }^{53}$.

Maquiavel pode ser entendido como o fundador do pensamento político moderno e, também, do pensamento político baseado na imanência. É na obra O Princípe, do florentino, que enxergamos o primeiro registro de um estado formado em bases humanas, sem a intervenção de Deus ou de elementos externos à humanidade. Ao descrever a formação dos principados, diz Maquiavel que:

\footnotetext{
51 "Hobbes declara que o rei é o povo dado que este último, ao contrário da multidão, é um sujeito único que pode se fazer representando por uma única pessoa. Em aparência, trata-se de distinção simplesmente geométrica: o povo é uno (e, portanto, capaz de exercitar a soberania) enquanto a multidão é plural (e incoerente e, por isso, incapaz de se auto-governar)".

HARDT, Michael; NEGRI, Antonio. Comune: oltre il privato e il publico. Alessandro Pandolf (trad.). $1^{\text {a }}$ ed. Milano: Rizzoli Libri, 2010. p. 61.

52 SILVA, Valeska S. Rodrigues. A Política da Multidão: a Constituição da Democracia do Comum no Pensamento de Antonio Negri. Rio de Janeiro. 2014. (Dissertação de Mestrado) Departamento de Direito da PUC-Rio; Dissertação apresentada no programa de Mestrado em Teoria do Estado e Direito Constitucional da PUC-Rio sob orientação do Prof. Adriano Pilatti em 2014. p. 30.

${ }^{53}$ É interessante notar que Antonio Negri estabelece uma linhagem sucessória de pensadores da imanência que começa em Maquiavel, passa por Spinoza, Marx e da qual ele diz fazer parte.

SILVA, Valeska S. Rodrigues. A Politica da Multidão: a Constituição da Democracia do Comum no Pensamento de Antonio Negri. Rio de Janeiro. 2014. (Dissertação de Mestrado) Departamento de Direito da PUC-Rio; Dissertação apresentada no programa de Mestrado em Teoria do Estado e Direito Constitucional da PUC-Rio sob orientação do Prof. Adriano Pilatti em 2014. p31.
} 
Todos os Estados, todos os domínios que tiveram e têm poder sobre os homens foram e são repúblicas ou principados. E os principados são: ou hereditários, nos quais o sangue de seu senhor tenha reinado por longo tempo, ou novos. E, entre os novos, ou são novos de todo, como foi o de Francesco Sforza em Milão, ou são constituídos de membros agregados ao Estado hereditário do príncipe que os conquista, como é o reino de Nápoles submetido ao rei da Espanha. Assim são ordenados tais domínios, uns habituados a viver sob um príncipe, outros acostumados a serem livres; e eles são conquistados ou por armas alheias ou por armas próprias. Ou por fortuna ou por virtude ${ }^{54}$.

O trecho transcrito mostra, com clareza, a existência de um fundamento material para o Estado no pensamento de Maquiavel, negando claramente a interferência de um elemento externo ou divino na obra do florentino o que, para a sua época, pode ser considerado revolucionário.

Em Maquiavel, há a fundação de uma política calcada na imanência, a partir dos conceitos de fortuna e virtú. A fortuna é comumente entendida como uma sucessão de eventos externos, sempre com efeito sobre a sociedade, e a virtú como a capacidade de superação destes eventos. Uma boa definição para estes conceitos, sob a ótica negriana, é dada por Silva, quem diz que:

Em termos de poder constituinte, a virtù é apresentada por Maquiavel, portanto, como a força coletiva de constituição de mecanismos de resistência aos imprevistos da fortuna, de modo que as coletividades possam evitar determinações externas a si mesmas ${ }^{55}$.

Ademais, em Maquiavel observamos também que a existência de uma política baseada na existência de conflitos sociais, uma vez que, conforme para ele a cidade seria dívida entre os "grandes", marcados por um desejo de opressão e os "pequenos", marcados por um desejo de não serem oprimidos que, para o florentino, se expressa como um profundo

\footnotetext{
${ }^{54}$ MAQUIAVEL, Nicolau. O Príncipe. DIAS, Maurício Santana (trad.). Dos apêndices de Luiz A. de Araújo. São Paulo, 2010.

${ }^{55}$ SILVA, Valeska S. Rodrigues. A Política da Multidão: a Constituição da Democracia do Comum no Pensamento de Antonio Negri. Rio de Janeiro. 2014. (Dissertação de Mestrado) Departamento de Direito da PUC-Rio; Dissertação apresentada no programa de Mestrado em Teoria do Estado e Direito Constitucional da PUC-Rio sob orientação do Prof. Adriano Pilatti em 2014. p.39.
} 
desejo de liberdade. Para ele, este conflito entre os grandes e os pequenos, entre os patrícios e a plebe, é que seria o fator principal da política ${ }^{56}$.

Espinoza, como Maquiavel, também baseia a sua filosofia na imanência, a partir do conceito que ele traça de causa sui, ou causa de si, ou seja, de algo cuja existência envolve sua própria essência. Portanto, se a existência de uma coisa decorre de sua essência, temos que, em primeiro lugar, não há influência de elementos transcedentais na sociedade e que, em segundo lugar, os seus efeitos dão-se no plano da imanência onde esta se encontra $^{57}$.

Em Espinoza, o conflito entre imanência e transcendência, que na obra de Maquiavel se traduz na oposição entre virtú e fortuna, está exposto como um conflito entre potência - definida como uma capacidade de agir com causa em si - e o poder - que é definido como um instrumento de comando com causas externas a si.

A potência, em Espinoza, constitui uma força que guia tudo que existe na perseverança de sua própria existência ${ }^{58} \mathrm{e}$, para ele, o poder se encontra subordinado a potência e, portanto, não haveria legitimidade em um governo de forma transcedental - como aquele proposto por Hobbes.

De Marx, por fim, Negri retira o método materialista, o qual ele “filtra” a partir das concepções de Maquiavel e Spinoza. Negri realiza este movimento para conseguir aplicar os conceitos marxianos ao capitalismo cognitivo, um momento histórico no qual os conceitos tradicionais de classe e, em especial, da classe operária, se mostram insuficientes para

\footnotetext{
${ }^{56}$ Para uma explicação mais aprofundada, recomendamos a leitura de sua obra Discursos sobre a primeira década de Tito Lívio.

57 SILVA, Valeska S. Rodrigues. A Política da Multidão: a Constituição da Democracia do Comum no Pensamento de Antonio Negri. Rio de Janeiro. 2014. (Dissertação de Mestrado) Departamento de Direito da PUC-Rio; Dissertação apresentada no programa de Mestrado em Teoria do Estado e Direito Constitucional da PUC-Rio sob orientação do Prof. Adriano Pilatti em 2014., p. 40.

${ }^{58}$ SILVA, Valeska S. Rodrigues. A Política da Multidão: a Constituição da Democracia do Comum no Pensamento de Antonio Negri. Rio de Janeiro. 2014. (Dissertação de Mestrado) Departamento de Direito da PUC-Rio; Dissertação apresentada no programa de Mestrado em Teoria do Estado e Direito Constitucional da PUC-Rio sob orientação do Prof. Adriano Pilatti em 2014.,. 41.
} 
compreender as novas composições sociais ${ }^{59}$. A intenção de Negri é atualizar a filosofia marxista a partir dos dados concretos do século $\mathrm{XXI}^{60}$.

Negri retira quatro "noções primordiais" do pensamento de Marx, que seriam: (i) tendência histórica; (ii) abstração real; (iii) antagonismo e (iv) produção de subjetividade ${ }^{61}$.

Resumidamente, essas noções corresponderiam à: (i) existência de padrões hegemônicos a transição entre períodos históricos, sendo o atual sob o paradigma do trabalho imaterial; (ii) noção de que todo o valor, no capitalismo, é produzido pelo trabalho e que, no atual paradigma, a quantificação do valor produzido em horas perde o sentido porque não há mais divisão entre hora de trabalho e hora de vida; (iii) de que a exploração é a tônica do capitalismo e que, no capitalismo cognitivo, como o trabalho imaterial também produz o comum, essa corresponde à sua expropriação e (iv) que o trabalho produz subjetividades modeladas no antagonismo da exploração o qual, para Negri, traduz-se melhor nos pobres.

Apesar do plano transcendente sagrar-se vencedor do conflito ${ }^{62}$ travado pela hegemonia da modernidade, não é capaz de eliminar completamente o plano imanente, motivo pelo qual este conflito permanece em vigor e, segundo Negri, constitui uma das forças motrizes da modernidade. Para entendermos como isto ocorre, estudaremos com maior

\footnotetext{
59 SILVA, Valeska S. Rodrigues. A Política da Multidão: a Constituição da Democracia do Comum no Pensamento de Antonio Negri. Rio de Janeiro. 2014. (Dissertação de Mestrado) Departamento de Direito da PUC-Rio; Dissertação apresentada no programa de Mestrado em Teoria do Estado e Direito Constitucional da PUC-Rio sob orientação do Prof. Adriano Pilatti em 2014.,p. 45.

Este tema será tratado de forma mais aprofundada no item 2.2 deste capítulo.

60 "à medida que a história avança e a realidade social se transforma, as velhas teorias deixam de ser aplicáveis. Precisamos de novas teorias para a nova realidade. (...) Em termos simplificados, para seguir os passos de Marx temos realmente de ultrapassá-lo, desenvolvendo, com base em seu método, um novo aparato teórico adequado à nossa atual situação".

HARDT, Michael; NEGRI, Antonio. Multidão: Guerra e Democracia na Era do Império. MARQUES, Clóvis (trad.). 2a ed. Editora Record, 2012, pg. 189

61 HARDT, Michael; NEGRI, Antonio. Multidão: Guerra e Democracia na Era do Império. MARQUES, Clóvis (trad.). 2a ed. Editora Record, 2012.p. 189.

62 "O conceito de constituição republicana, depois democrática e enfim socialista é reproposto sem cessar como tentativa de fundar um 'político' que consiga alicerçar sua legitimidade no poder constituinte do 'social'e nos antagonismos que nele estão presentes. Mas essa continuidade é negativa. De fato, o projeto fracassa sempre".

NEGRI, Antonio. O poder constituinte: ensaio sobre as alternativas da modernidade. PILATTI, Adriano (Trad.). $2^{\mathrm{a}}$ ed. Rio de Janeiro: Lamparina, 2015. p. 316.
} 
profundidade agora o que significa o poder constituinte na obra de Antonio Negri.

\subsection{O Poder Constituinte}

Antes de entrarmos no conceito negriano, é forçoso introduzirmos a definição tradicionalmente atribuída, pelos estudiosos do direito constitucional, ao poder constituinte, uma vez que Negri diverge frontalmente desta, conforme veremos a seguir.

Tradicionalmente, a "descoberta" do poder Constituinte é atribuída ao abade francês Emmanuel Sieyés ${ }^{63}$ na sua obra "A constituinte burguesa: O que é o Terceiro Estado", publicada em fevereiro de 1789, quando da convocação, por Luíz XVI, dos Estados Gerais, que na época não se reunia há duzentos anos. O órgão possuía esse nome por ser formado pelos três "Estados" que compunham a sociedade francesa: o primeiro, a nobreza; o segundo, o clero e o terceiro formado pelos "comuns", desprovidos de privilégios legais. Como os votos eram tomados por Estado, embora os comuns fossem a maioria da população, constituíam um terço dos Estados Gerais e, por isso, eram sempre derrotados nas votações.

Por este motivo, o Terceiro Estado rompe com os outros dois e forma a "Assembléia Geral Constituinte". A teoria elaborada por Sieyès oferece uma justificativa intelectual para este processo, uma vez que ele fundamentava o poder constituinte na Nação, cuja manifestação seria feita através de representantes eleitos para esta finalidade. Como explicam Sarmento e Ferreira "o poder constituinte estruturaria o exercício do poder político, determinando os termos em que as autoridades públicas, inclusive

\footnotetext{
${ }^{63}$ Além do próprio Negri, ao abordar a posição do constitucionalismo tradicional, outros autores como Francisco de Guimaraens e Daniel Sarmento, em obra escrita em conjunto com Cláudio Pereira de Souza, que dizem que "Foi Emanuel Sieyès, nos momentos preliminares da Revolução Francesa, quem formulou a versão mais conhecida do conceito de poder constituinte, traçando contornos que, até hoje, com pequenas modificações, representam a ortodoxia no assunto". NETO, Claudio Pereira de Souza. SARMENTO, Daniel. Direito Constitucional: teoria, história e métodos de trabalho. $2^{\mathrm{a}}$ ed. Belo Horizonte: Fórum, 2014. p. 245.
} 
os legisladores, poderiam atuar licitamente atuar"64. A função do poder constituinte, todavia, em Sièyes, esgota-se aí: ele cria as instituições e estabelece seus limites, mas sua atuação não gera outros efeitos. Trata-se, portanto, de um conceito limitado, finito e com escopo bem definido: criar as instituições e delimitar o seu funcionamento regular.

Este processo retira o conflito da definição de poder constituinte, atribuindo-lhe uma finalidade prévia, a qual limita o seu escopo de funcionamento. O constitucionalismo tradicional é, portanto, como diz Francisco Guimaraens, "um meio de aprisionamento do poder constituinte nas teias da transcendência" ${ }^{\circ 5}$. Essa caráter fica claro na definição de Poder Constituinte formulada por Sarmento:

Um dos conceitos centrais do Direito Constitucional é o de Poder Constituinte. Trata-se do poder de criar a Constituição e de fundar ou refundar o Estado e a ordem jurídica. A expressão 'poder constituinte' também é empregada para designar o poder de modificar a Constituição, bem como o de elaborar, nos Estados federais, as constituições estaduais. Estes últimos são tidos como expressão do chamado poder constituinte derivado, que se subdivide, respectivamente, em poder de reforma da Constituição e poder constituinte decorrente ${ }^{66}$.

Nada poderia ser mais diferente do conceito formulado por Antonio Negri, que é atemporal, infinito, ilimitado e, sobretudo, imanente. Em Negri, o poder constituinte é antes de tudo potência, expansível e mutável. Não é, entretanto, um conceito "dado" ou facilmente apreensível, mas sim construído pelo autor a partir da análise minuciosa de uma série de autores e processos históricos, conforme o seguinte roteiro: Começando em Maquiavel, a partir da análise dos conceitos de virtu e fortuna, de quem retira a capacidade de mutação ininterrupta do poder constituinte; passando pelo filósofo britânico John Harrington, de onde apreende o conceito de

\footnotetext{
${ }^{64}$ NETO, Claudio Pereira de Souza. SARMENTO, Daniel. Direito Constitucional: teoria, história e métodos de trabalho. $2^{\mathrm{a}}$ ed. Belo Horizonte: Fórum, 2014 p. 245.

${ }^{65}$ GUIMARAENS, Francisco de; O poder constituinte na perspectiva de Antonio Negri: um convite muito além da modernidade hegemônica. $1^{\mathrm{a}}$ ed. Rio de Janeiro: Editora Forense, 2004, p. 179.

66 NETO, Claudio Pereira de Souza. SARMENTO, Daniel. Direito Constitucional: teoria, história e métodos de trabalho. $2^{\mathrm{a}}$ ed. Belo Horizonte: Fórum, 2014. p. 245.
} 
poder constituinte como um contra-poder; do processo de independência dos EUA, da qual Negri retira a sua expansividade para além dos limites existentes; chegando à Revolução Francesa, faz-se uma análise da temporalidade do poder constituinte, diferente daquela que dita o curso normal dos acontecimentos e chegando, por fim, à Revolução Russa da qual, a partir da análise da obra de Marx, ele retira um poder constituinte como trabalho vivo. Além dos citados, Negri conta com a generosa contribuição de Spinoza, de quem tira a idéia de poder constituinte como potência.

Para entender o poder constituinte em Negri, portanto, precisamos refazer este roteiro, explicitando o que, em cada período ou obra citada, chamou a atenção do filósofo italiano, o que procederemos a fazer agora.

Antes de prosseguirmos, cumpre avisar que Negri realiza uma leitura contra-hegemônica da obra de Maquiavel. Enquanto que a leitura hegemônica, feita pelos franceses, transforma o florentino em um teórico da "modernização absoluta do Estado" "67. a leitura feita por Negri, e que tem raízes no pensamento inglês, vê em Maquiavel "o autor que faz a introdução á crítica do poder constituído, à análise das classes sociais, ao conceito e à prática da militia popular como poder constituinte" ${ }^{\mathrm{6}}$.

Ao interpretar estes conceitos, Negri afirma que, na obra maquiaveliana, as mutações deixam de pertencer o destino, a fortuna, e se transformam em elementos da história, capazes de serem alterados pela ação humana, o que se dá mediante a virtú, que pode então ser entendida como uma capacidade de produzir eventos singulares.

\footnotetext{
${ }^{67}$ É importante ressaltar que, para Negri, essa operação ocorre propositalmente como forma de extirpar, da obra de Maquiavel, a sua potência revolucionária e sua defesa da liberdade. NEGRI, Antonio. O poder constituinte: ensaio sobre as alternativas da modernidade. PILATTI, Adriano (Trad.). $2^{\mathrm{a}}$ ed. Rio de Janeiro: Lamparina, 2015. p. 110.

${ }^{68}$ NEGRI, Antonio. O poder constituinte: ensaio sobre as alternativas da modernidade. PILATTI, Adriano (Trad.). $2^{\mathrm{a}}$ ed. Rio de Janeiro: Lamparina, 2015. p 111.
} 
Outro ponto importante que Negri aponta na obra maquiaveliana, desta vez nos Discorsi $^{69}$, é a presença da República, em especial do modelo romano, como o mais bem sucedido formato de governo possível. Isto aconteceria justamente por causa da abertura que a República, em Roma, tinha aos tumultos causados pela plebe ${ }^{70}$. Nas palavras de Francisco de Guimaraens, a "República aparece, neste sentido, como experiência de certa mutação e também como espaço que confere as condições de possibilidade para a permanência desta mutação"

Da obra de Maquiavel, Negri retira, para seu conceito de poder constituinte, a mutação capaz de superar a temporalidade cíclica (chronos) e se abre para uma nova temporalidade, baseada na produção de eventos singulares (kairós).

Dando prosseguimento a sua análise, Negri aborda o pensamento de John Harrington, um pensador britânico. Assim como na obra de Maquiavel, aqui o poder constituinte também aparece como uma tensão permanentemente em aberto mas, e neste ponto Harrington vai além do florentino, ele adiciona também o caráter de contrapoder ao poder constituinte, que se expressa, como diz Francisco Guimaraens, não apenas na resistência mas também em atuar "conformando o próprio poder constituído a partir da afirmação de um projeto político-existencial singular e concreto" $" 72$.

\footnotetext{
69 Discorsi sopra la prima deca di Tito Livio, títluo em italiano dos "Discursos sobre a primeira década de Tito Lívio".

70 "Em suma, foi no confronto entre essas classes ou coletividades que Machiavelli identificou ao mesmo tempo a necessidade e a condição de possibilidade da criação de instituições que servissem à liberdade, pois a história de Roma teria demonstrado que os patrícios tendiam a destruição dela e os plebeus, à conservação dela".

PILATTI, Adriano. A plebe multutidinária e a constituição de seus tribunos na sociedade global. $\mathrm{n}^{\mathrm{o}}$ 34. Revista Direito, Estado e Sociedade. Departamento de Direito da PUC-Rio, p. 7

${ }^{70}$ PILATTI, Adriano. A plebe multutidinária e a constituição de seus tribunos na sociedade global. $n^{\circ}$ 34. Revista Direito, Estado e Sociedade. Departamento de Direito da PUC-Rio, p. 7.

${ }^{71}$ GUIMARAENS, Francisco de; O poder constituinte na perspectiva de Antonio Negri: um convite muito além da modernidade hegemônica. $1^{\text {a }}$ ed. Rio de Janeiro: Editora Forense, 2004, p. 150 .

72 GUIMARAENS, Francisco de; O poder constituinte na perspectiva de Antonio Negri: um convite muito além da modernidade hegemônica. $1^{\text {a }}$ ed. Rio de Janeiro: Editora Forense, 2004, p.151.
} 
Para Harrington, o poder está intrinsecamente ligado à propriedade e, portanto, a distribuição igualitária da propriedade se torna fundamental para a liberdade e, por este motivo, ele defende a adoção de uma lei agrária que garanta uma melhor distribuição das terras para a agricultura.

A partir do momento que traça uma alternativa, defendendo uma mudança legislativa na estrutura proprietária e, consequentemente, uma alteração na estrutura de poder social, Harrington propõe um conceito de poder-constituinte que, através da limitação da propriedade, atua no sentido de reestruturar o sistema, tornando-o permeável à influência da multidão.

Na revolução americana, Negri analisa a experiência constituinte que levou à independência daquele país, concluindo pela predominância de um caráter expansivo do poder constituinte. Para ele, este processo estava intrinsecamente ligado à concepção atribuída à propriedade no início da expansão americana a qual era concebida como obtida através do trabalho.

Essa expansividade, somada a uma Constituição aberta à influência do poder constituinte, geram uma experiência de liberdade e que estabelece como características do poder constituinte o seu senso de expansividade, coletividade e apropriação a partir do trabalho vivo da multidão.

Da experiência revolucionária francesa, Negri retira a temporalidade do poder constituinte. Segundo ele, neste caso, as massas, a partir de sua organização, apropriaram-se do tempo ao negar as formas burguesas de organizá-lo em torno do trabalho.

Para Negri, irrupção do poder constituinte rompe com a lógica do poder constituído, inclusive na regulação cronológica - ao conceito de cronos, o tempo regular dos acontecimentos, Negri opõe o kairós, o tempo da multidão, "o momento em que a flecha é atirada pelo arco, o momento em que é hora de agir" ${ }^{\text {"73. }}$.

\footnotetext{
${ }^{73}$ HARDT, Michael; NEGRI, Antonio. Multidão: Guerra e Democracia na Era do Império. MARQUES, Clóvis (trad.). $2^{\mathrm{a}}$ ed. Editora Record, 2012. p. 446.
} 
A ação do poder constituinte, portanto, rompe com o temporalidade através da força da multidão, que o comprime e o modula a partir da sua potência, gerada, conforme veremos, pelo encontro de suas singularidades.

Por fim, Negri analisa a experiência da revolução russa e também da obra de Marx. Para Negri, o sentido real do poder constituinte no comunismo é a ruptura com a modernidade transcedental, representada pelo capitalismo. Contra a apropriação, é proposta a cooperação.

Marx detecta uma alienação da potência produtiva do poder constituinte, sob a organização do capital. Os trabalhadores cooperam entre si, mas tudo o que produzem é, conforme explicitado em nosso tópico anterior, imediatamente apropriado.

O poder constituinte, que aí se apresenta como o trabalho vivo resultante da cooperação entre os trabalhadores, encontra-se, portanto, aprisionado dentro das regulações ordenadas pelo capital.

Em Marx, portanto, o poder constituinte ganha também dimensão socioeconômica da qual não pode ser dissociado. A produtividade, que se revela através da cooperação da multidão, é inerente ao poder constituinte, o qual somente pode ser pleno quando livre das amarras do capital.

Tendo observado a definição negriana do poder constituinte e a forma a partir da qual o pensador italiano chegou a formulação de seu conceito, passamos agora ao passo seguinte de nosso trabalho, que é a análise do conceito de multidão

\subsection{Que é a multidão?}

O conceito de multidão não é um conceito simples de se definir. De fato, tamanha é a dificuldade em empreender esta tarefa que a maioria dos autores que conduziram estudos sobre o tema terminam por não fazê-lo, sendo a abordagem mais comum uma análise das suas características e dos processos sociais que a possibilitam . Isso se dá pela sua própria natureza que, conforme veremos adiante, é expansível e mutável. O que pretendemos 
aqui, portanto, não é buscar uma definição, mas sim analisar, em linhas gerais: (i) os processos sociais que permitiram que a multidão se firmasse como o sujeito hegemônico das lutas no capitalismo cognitivo e (ii) o que constitui a multidão e qual é a sua natureza.

Como Virno aponta em seu livro "Gramática da Multidão", o conceito de multidão não é uma novidades no pensamento político/filosófico. Com efeito, as primeiras referências a este conceito datam já do Século XVII, na forma de um conflito entre a multidão e o povo, o qual se traduz na querela doutrinária entre Spinoza e Hobbes, a qual já foi abordada nesse trabalho. Retornaremos a ela brevemente apenas para fazer uma ponte entre os pensamentos de Virno e ascenção da multidão como sujeito político hegemônico do capitalismo cognitivo.

Spinoza, conforme ressalta Virno, concebe a multidão como uma pluralidade, a qual permaneceria como tal sem convergir para o Uno. Já

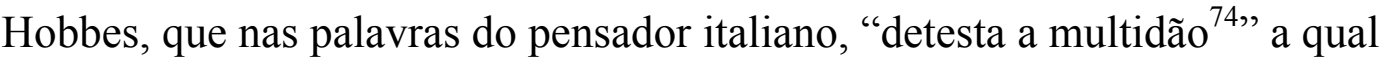
ele atribui, conforme vimos, o caráter de "estado de natureza". A solução hobbesiana, portanto, para impedir que a mulitdão destruísse a si própria seria unificá-la, transformando-a em um sujeito governável.

Para Virno, povo e multidão são forças opostas. O povo seria uma força centrifuga, partindo de um exterior múltiplo e centralizando essas multiplicidades em torno de uma única figura. Já a multidão funcionaria como uma força centrípeta, ou seja, partindo de um uno - ao qual Virno vai atribuir o nome de comum pré-individual - para um múltiplo a partir do processo de individuação.

O motivo para a multidão ter se tornado, portanto, o sujeito hegemônico está ligado ao fato de que os meios de produção adotados pelo capitalismo, no seu estágio atual, favorecem o seu desenvolvimento, em detrimento do povo, que se torna um conceito cada vez mais inadequado para a compreensão dos fenômenos sociais modernos.

\footnotetext{
74 In VIRNO, Paolo; Gramática da Multidão: para uma análise das formas de vida contemporâneas; São Paulo; Annablume, 2013, $1^{\text {a }}$ ed.
} 
Para o filósofo italiano, isso acontece em função da inversão de posições entre a esfera pública e a esfera privada na sociedade moderna. Para analisar esse ponto, ele parte dos topoi koinoi, ou lugares comuns, da linguagem, presentes na filosofia de Aristóteles. Para ele, os topoi koinoi constituem a base do pensamento lógico de qualquer locução verbal e se constituem em três categorias: mais e menos; oposição e contraste e reciprocidade. A partir deles, o intelecto é capaz de produzir os chamados toipoi idioi, ou lugares particulares.

Tradicionalmente, os toipoi idioi se manifestavam de forma publica, sendo produzidos a partir do conteúdo daqueles. Virno observa uma mudança nesse andamento social que inverte a direção deste processo e faz com que os topoi koinoi tomem o lugar dos toipoi idioi como manifestação pública do intelecto.

Virno assemelha esse processo àquele pelo qual passa um imigrante ao se adaptar a um novo país. Com efeito, quando um imigrante muda de nação - e, consequentemente, de idioma - apenas está familiarizado com os topoi koinoi e, por isso, tem sua vida intelectual limitada a eles.

A resultante deste fenômeno, para Virno, é a publicização do intelecto, ou seja, o surgimento de formas de comunicação cuja base é apenas o topoi koinoi. Para o pensador italiano, isto torna a vida do intelectual mais parecida com a do imigrante, uma vez que o processo linguístico percorrido por ambos torna-se o mesmo. Isso leva a um dos elementos que, para Virno, constituem a Multidão: um não sentir-se em casa permanente.

A publicização do intelecto gera mudanças na própria estrutura do trabalho, o qual passa a perder a sua divisão característica da primeira etapa do capitalismo. Para entender como isso acontece, precisamos analisar as características de alguns elementos que Virno reputa centrais e que vem perdendo sua essência, fundindo-se entre si. Tratam-se das categorias do Trabalho, da Ação Política e do Intelecto. 
Em linhas gerais, Virno sustenta que estas categorias, no alvorecer do capitalismo, encontravam-se separadas e com fronteiras bem demarcadas: trabalho se caracterizava por ser uma ação repetitiva, que agia diretamente sobre a natureza, modificando-a; a ação política possuía como traços distintos a sua publicidade e o seu agir diretamente sobre as pessoas e, por fim, o intelecto atuava apenas na esfera privada e de forma solitária, ou seja, não aparente.

Com a passagem para a fase do capitalismo cognitivo, Virno sustenta que as fronteiras entre essas áreas tornam-se tênues e elas passam a assumir uma características das outras: o trabalho perde o seu caráter repetitivo e passa também a afetar a natureza humana, como a ação política, a qual, por sua vez, assume algumas das características antigas do intelecto e este ,por sua vez, passa a tornar-se público.

O resultado deste processo, para Virno, é que o trabalho passa a assumir características diferentes, assemelhando-se ao que ele chama de "virtuosismo" - o qual, aliás, ele define como sendo típico da compreensão tradicional da ação política. Para ele, as principais características do virtuosismo são a sua finalidade, que é em si mesmo, ou seja, não há um produto final a ser guardado e a necessidade de um público para testemunhar a obra. A atividade básica do virtuosismo, para Virno, seria a do uso da linguagem. Neste sentido, não só somos todos virtuosos como também somos constantemente produtivos.

Estas características são típicas do chamado trabalho imaterial o qual, dentro do capitalismo cognitivo, se torna forma hegemônica de produção. Da mesma forma que o marxismo tradicional entende o trabalho fabril como a forma hegemônica de trabalho e a classe operária como o sujeito principal deste, em Negri fica claro que, com a ascenção do capitalismo cognitivo, a multidão se torna a classe antagonista ao capitalismo, abrangindo todos aqueles que produzem sob o capital. 
A hegemonia do trabalho imaterial não se traduz, necessariamente, em uma redução numérica de postos de trabalho material, mas sim com a assimilação, por parte destes, das caracteristícas típicas do trabalho imaterial do capitalismo cognitivo.

Desta forma, observamos um domínio cada vez maior do trabalho sobre a vida. Com a maior flexibilidade e informalidade dos postos de trabalho, observa-se também o aumento das horas dedicadas a ele, que passa a dominar todas as esferas da vida. A multidão se torna constantemente produtiva e a sua produção é sempre apropriada pelo capital.

O trabalho imaterial, como estabelecido por Hardt e $\mathrm{Negri}^{75}$ tem como paradigma central a produção do comum a partir do encontro dos afetos e singularidades. $\mathrm{O}$ trabalho imaterial é sempre afetivo e, a partir dele, a criação de cooperação se torna interna ao próprio funcionamento do capital, uma vez que o trabalho imaterial somente pode ser realizado em comum.

Dentro deste paradigma, não há diferença entre tempo trabalhado e tempo vivido, de forma que todos somos, o tempo todo, produtivos e nossa produtividade é constantemente apropriada pelo capital.

A multidão é, por sua própria natureza, a classe hegemônica do trabalho imaterial. Para compreendermos esta um pouco melhor, seguiremos o roteiro também observado por Hardt e Negri em sua obra "Multidão: Guerra e Democracia na era do Império", estudaremos primeiro a definição de multidão a contrario sensu, partindo de três conceitos distintos (povo, massa e classe operária) para depois analisarmos elementos constitutivos da multidão.

Conforme já dito anteriormente, ao falarmos sobre o povo devemos, em primeiro lugar, lembrar a unicidade do mesmo. Com efeito, conforme afirmam Hardt e Negri:

\footnotetext{
75 HARDT, Michael; NEGRI, Antonio. Multidão: Guerra e Democracia na Era do Império. MARQUES, Clóvis (trad.). 2a ed. Editora Record, 2012. p. 195.
} 
O povo tem sido tradicionalmente uma concepção unitária. A população, como se sabe, é caracterizada pelas mais amplas diferenças, mas o povo reduz esta diversidade a uma unidade, transformando a população numa identidade única: o 'povo' é uno ${ }^{76}$.

De fato, esta conceituação unitária de povo pode ser observada mesmo em pensadores de viés mais tradicionalista, como Paulo Bonavides que, conceitua o povo política e juridicamente das seguintes formas, respectivamente:

Povo é então o quadro humano sufragante, que se politizou (quer dizer, que assumiu capacidade decisória), ou seja, o corpo eleitoral (grifo nosso). O conceito de povo traduz por conseguinte uma formação histórica recente, sendo estranho ao direito público das realezas absolutas, que conheciam súditos e dinastias, mas que não conheciam povos e nações ${ }^{77}$.

Com efeito, o povo exprime o conjunto de pessoas vinculadas de forma institucional e estável a um determinado ordenamento jurídico ou, segundo Ranelletti, 'o conjunto de indíviduos vinculados pela cidadania a um determinado ordenamento jurídico $^{78}$.

A multidão, por sua vez, é formada pelo encontro de singularidades. Logo, ela não pode ser reduzida a um conceito uno, uma vez que ela é, na verdade, uma multiplicidade.

A multidão também é diferente das massas. As massas, ao contrário do povo, não são unas. O que implica afirmar, portanto, que dentro conceito de massas cabem distintas etnias e pessoas diferentes, ou seja, não podem ser reduzidas a uma unidade. Todavia, conforme pontuam Hardt e Negri, "a essência das massas é a indiferença",79

Ao afirmar isso, queremos dizer que as massas não respeitam as singularidades que as compõem. Diferentemente da multidão, nas quais as diferenças são aceitas e combinadas entre si para tornarem-se uma potência,

\footnotetext{
76 HARDT, Michael; NEGRI, Antonio. Multidão: Guerra e Democracia na Era do Império. MARQUES, Clóvis (trad.). $2^{\mathrm{a}}$ ed. Editora Record, 2012., p. 12.

${ }^{77}$ BONAVIDES, Paulo. Ciência Política. $19^{\mathrm{a}}$ ed. São Paulo: Malheiros Editores, 2012. p. 80.

${ }^{78}$ BONAVIDES, Paulo. Ciência Política. $19^{a}$ ed. São Paulo: Malheiros Editores, 2012. p. 81.

79 HARDT, Michael; NEGRI, Antonio. Multidão: Guerra e Democracia na Era do Império. MARQUES, Clóvis (trad.). 2a ed. Editora Record, 2012., p. 13.
} 
nas massas, como dizem de forma muito poética Hardt e Negri, "todas as cores da população reduzem-se ao cinza" ${ }^{\natural 0}$.

Por fim, precisamos diferenciar a multidão da classe operária. No pensamento marxista tracional, o trabalho fabril representa o trabalho hegemônico dentro do sistema capitalista. Por isso, a classe operária, que seria aquela que laborava nas fábricas, seria uma classe diferenciada ${ }^{81} \mathrm{de}$ trabalhadores sobre as quais caberia a primazia na condução da luta contra o capitalismo.

Podemos deduzir, daí, que o conceito de classe operária é um conceito restrito, posto que não abrange em sua definição outros tipos de trabalhadores, como os trabalhadores rurais, do setor de serviços e tantos outros. A multidão, por outro lado, é um conceito aberto e que acompanha as mudanças mais recentes na economia global. De fato, a classe operária, embora de importância histórica inegável, não desempenha mais um papel central na economia global. Mesmo que seu contingente não tenha sofrido grandes alterações, as novas formas de produção surgidas nas últimas décadas fizeram com que este conceito ficasse, em parte, obsoleto.

É importante ressaltar que, no atual estado do capitalismo, não há mais diferença entre o tempo do trabalho e o tempo de vida. O que implica dizer que somos todos produtivos o tempo todo, mesmo aqueles que não se enquadravam nos conceitos de produtividade anteriores, aqueles excluídos do sistema: os pobres, a quem Hardt e Negri atribuem uma potência transformadora que está no centro da produção do comum.

Hardt e Negri consideram a existência de duas multidões: uma do ponto de vista ontológico a qual cria uma liberdade absoluta e que se manifestaria através da recusa, por parte das pessoas, à autoridade e comando e a outra é a multidão do ponto de vista histórico, que é política, a

${ }^{80}$ HARDT, Michael; NEGRI, Antonio. Multidão: Guerra e Democracia na Era do Império. MARQUES, Clóvis (trad.). 2a ed. Editora Record, 2012. p13.

81 "o conceito de classe trabalhadora passou a ser usado como um conceito exclusivo, não apenas distinguindo os trabalhadores dos proprietários que não precisam trabalhar para se sustentar, mas também separando a classe operária de outros que trabalham".

HARDT, Michael; NEGRI, Antonio. Multidão: Guerra e Democracia na Era do Império. MARQUES, Clóvis (trad.). 2 ${ }^{\mathrm{a}}$ ed. Editora Record, 2012. p. 13. 
qual eles dizem nunca ter aparecido em função da ausência de condições políticas, jurídicas, econômicas e culturais.

Isso equivaleria, explicando de uma forma simplificada, a dizer que não existe, ainda, a multidão, de uma forma concreta. O que existiria, segundo os autores, seriam duas multidões distintas: a primeira composta por elementos pertinentes à multidão, dentre as quais eles elencam a sua potência e seu desejo de liberação e que se manifestam de formas esporádicas ao longo da história, a qual eles atribuem um sentido ontológico e a segunda seria uma multidão em sentido histórico e que dependeria de determinados elementos políticos, jurídicos, econômicos e sociais para se manifestar, os quais não ocorreram em momento algum, até agora embora, recentemente, tenham começado a manifestar-se de forma embrionária.

O objetivo do nosso próximo capítulo é averiguar se as Jornadas de Junho podem ser entendidas como um dos episódios em que caracteristícas dessa multidão histórica puderam ser observadas. 


\title{
CAPÍTULO 3 - OUTRO MUNDO BATE À PORTA: AS JORNADAS DE JUNHO
}

\subsection{Breves apontamentos sobre as revoltas multitudinárias}

Tem-se observado, nos últimos anos, um novo ciclo de revoltas espalhando-se pelo globo. Sustentamos que os levantes juninos serviram para incluir o país em um novo ciclo de manifestações, cuja origem podemos traçar nos levantes em Seattle e Genova, no final do século passado, chegando à Primavera Árabe, passando pelo Occupy Wall Street $\mathrm{e}$ também pelos protestos na Turquia, sendo estes últimos uma das principais influências para as manifestações de junho de 2013 no Brasil - influência eternizada no grito "acabou o amor, isso aqui vai virar a Turquia", que ecoava nas ruas. Acreditamos que eles constituam manifestações

Essas manifestações tem como fio condutor a defesa do comum e organização da multidão em luta. Sabemos que a multidão não possui uma forma específica de luta, devido ao seu caráter expansivo, produtivo e abrangente, mas concordamos com Michael Hardt quando ele diz que:

\begin{abstract}
Dizer que as revoltas surgidas nas ruas de Rio e São Paulo, em 2013, foram organizadas na forma da multidão significa dizer que, - em vez de dirigas pelo partido, ou uma direção centraizada ou mesmo um comitê de liderança acima das massas, - os movimentos foram auto-organizados, conectados horizontalmente pelo território social. Os movimentos não foram ( e não se esforçam por ser) unificados e homogêneos, mas sim encontraram meios adequados para exprimir suas diferenças e antagonismos internos - e apesar de (ou por causa de) suas diferenças, descobriram maneiras de troca comum e cooperação, gerando uma série de demandas e perspectivas agrupadas na luta. Tal multidão não é desorganizada e não se forma espontaneamente, ao invés disso, ela requer uma atividade constante e intensa de organização ${ }^{82}$.
\end{abstract}

No caso turco, ao qual dedicamos um olhar mais atento por ter sido o que mais influenciou nas jornadas de junho em território brasileiro, os manifestantes se organizaram em torno da defesa da praça Taksim, a qual o

\footnotetext{
${ }^{82}$ Prefácio escrito por Michael Hardt ao livro Amanhã vai ser maior, coletânea de artigos sobre as Jornadas de Junho, organizada por Giuseppe Cocco e Bruno Cava.
} 
governo turco desejava entregar à iniciativa privada para a construção de uma praça, o que causou grande revolta em Istambul e gerou a ocupação do Parque Gezi. Esse movimento teve intensa repercussão nas jornadas de junho em função da proximidade cronológica entre os dois eventos e também da intensa divulgação, pela mídia e pelas redes, das imagens e vídeos do que acontecia naquele país.

Entre as características comuns que unem os movimentos que constituem este ciclo de revoltas, podemos listar algumas delas que contribuem para que consideremos estas como revoltas da multidão de fato: (i) organização descentralizada a partir das redes; (ii) articulação em torno do comum, recusando o público e o privado e (iii) e formas de manifestação que também são produtivas, a partir do momento em que também produzem o comum.

A multidão, como já sabemos, é composta por uma multiplicidade de singularidades. Ela não conhece, portanto, hierarquias ou lideranças. Tudo é feito de forma imanente, a partir do conflito interno gerado pelo constante encontro de singularidades a partir dos fluxos de comunicação. A comunicação em rede, pela internet, potencializou estes encontros. Negri e Hardt comparam a forma de organização política da multidão com a linguagem, no sentido em que:

Com efeito, a multidão organiza-se como se fosse uma linguagem. Todos os elementos de uma linguagem são definidos por suas diferenças em relação uns aos outros, e no entanto todos eles funcionam juntos. Uma linguagem é uma rede flexível de significados que se combinam de acordo com regras aceitas numa infinidade de maneiras possíveis. Uma expressão específica, portanto, é não apenas a combinação de elementos linguísticos, mas a produção de significados reais: a expressão da nome a um acontecimento. Assim como da expressão surge a linguagem, portanto, uma decisão surge multidão de maneira a dar significado ao todo e a dar nome a um acontecimento. Para a expressão linguística, contudo, deve haver um sujeito separado que utilize a linguagem na expressão. É este o limite da nossa analogia, pois, ao contrário da linguagem, a multidão é ela própria um sujeito ativo - algo como uma linguagem capaz de expressar a si mesma",33.

\footnotetext{
${ }^{83}$ HARDT, Michael; NEGRI, Antonio. Multidão: Guerra e Democracia na Era do Império. MARQUES, Clóvis (trad.). $2^{\mathrm{a}}$ ed. Editora Record, 2012. p. 424.
} 
A multidão constitui, portanto, uma rede flexível articulada em torno dos comuns. Com efeito, um dos marcos desse novo ciclo global de lutas é a recusa do projeto da modernidade transcendente calcada na pilhagem dos comuns. Michael Hardt da o exemplo da Turquia, pais no qual, conforme ele relata:

\begin{abstract}
"A fagulha dos protestos turcos se deu com a resistência ao plano neoliberal de privatizar o espaço público - no caso, a construção de um shopping center imitando os antigos quartéis da cidade bem no parque central da cidade. Os movimentos, por um lado, se opuseram à privatização. Mas, por outro lado, também se opuseram ao controle público (quer dizer, estatal) do espaço urbano. No curso da luta, o movimento tornou o parque e a circunvizinha Praça Taksim um espaço comum aberto a todos e e organizado segundo mecanismos de governança democrática. Esse desejo por um comum através de Instambul e além é uma maneira de exprimir o direito a metrópole."
\end{abstract}

Através das suas pautas, estes movimentos reivindicam para si a própria cidade como um comum, o que engloba a sua segurança, o direito de transitar por ela livremente e usufruir da totalidade de seus serviços - no Rio, como veremos, isto se manifesta a partir da recusa de um projeto de cidade "mercadoria", claramente voltado para as camadas mais ricas e que teve nos mega eventos que a cidade recebeu uma das chaves para a sua implementação.

Além disso, a própria multidão, pelas formas através das quais organiza e demanda suas pautas, também se torna produtiva, como no caso das ocupações, forma de protesto cuja própria base é a vivência em comum e a interação entre múltiplas singularidades.

O objetivo dos nossos tópicos seguintes é, portanto, a luz do que foi examinado é demonstrar como as Jornadas de Junho se enquadram dentro destas revoltas multitudinárias a partir de dois pontos: (i) demonstrando que seus antecedentes estão ligados à apropriação do comum 
e que, portanto, houve por parte dos manifestantes uma real intenção de defendê-lo e (ii) refazendo a narrativa daqueles meses para apontar onde se encontram as caracteristícas típicas destas revoltas.

\subsection{Antecedentes}

O Brasil parecia viver um período histórico muito tranquilo. A economia, de vento em popa, havia sido uma das menos abaladas pela crise econômica de 2008. As políticas sociais multiplicavam-se e, com elas, a condição de vida de milhões de brasileiros melhorava significativamente. $\mathrm{O}$ governo gozava de altos índices de popularidade. A Copa das Confederações da FIFA estava para começar e, com ela, iniciaria o ciclo de eventos que consolidariam a imagem do Brasil grande no mundo. Tudo parecia, de fato, muito bem.

Eis que, de um momento para o outro e sem causa aparente, o país é sacudido de cima abaixo por manifestações maciças, algumas chegando a contar milhões de participantes. Nas ruas, vários gritos ecoavam "Não vai ter Copa!"; "Cadê o Amarildo?"; "Isso aqui vai virar a Turquia!"; "Eu quero o fim da Polícia Militar!” etc. Por toda a sociedade, ecoava a seguinte pergunta: o que está acontecendo?

Embora sem causa aparente, podemos apontar alguns fatores que tiveram um importante papel na erupção da multidão nas ruas brasileiras no ano de 2013. Tipicamente, ao falar do movimento em caráter nacional, são destacados como causas o desgaste do chamado "lulismo" e também a crise do sistema representativo que, como percebemos ao ver os acontecimentos ao redor do planeta $^{84}$.

\footnotetext{
${ }^{84}$ No momento em que essas linhas são escritas, Donald Trump acaba de ser eleito presidente dos EUA, tendo como um de seus maiores trunfos o fato de ser percebido, pela população norteamericana, como um nome de fora da política. Quase $50 \%$ dos eleitores não votou. Nas eleições municipais do Rio de Janeiro, nulos e brancos tiveram mais votos que os dois candidatos que foram para o segundo turno. O fato de votações assim se replicarem ao redor do globo é um indicativo claro do cansaço que os eleitores demonstram com as alternativas postas pelo sistema tradicional.
} 
Além disso, considerando que o objetivo de nosso trabalho é analisar em particular os acontecimentos na cidade do Rio de Janeiro, não podemos deixar de falar nos Megaeventos, principalmente a Copa do Mundo e as Olimpíadas, por meio dos quais foi deflagrado um processo acelerado de apropriação - ou "pilhagem" - das riquezas comumente produzidas pela população carioca.

Embora outras cidades também tenham sido vitimadas pelas mesmas circunstâncias, é importante ressaltar que em nenhuma delas o impacto foi igual ao sentido no Rio de Janeiro, sobretudo considerando que a cidade era importantíssima para a simbologia do "Brasil forte" que se desejou transmitir ao mundo com os Megaeventos. Ademais, o Rio, além de ter recebido a Copa do Mundo e a Copa das Confederações, foi a única sede dos Jogos Olimpícos de 2016 e, por isso, tornou-se o epicentro deste projeto.

Acreditamos que este processo tenha servido para intensificar os protestos no Rio que, não por acaso, tornou-se o epicentro do terremoto que abalou a República e foi a cidade onde os protestos foram maiores e mais duradouros - o ciclo de junho aqui durou até novembro.

Portanto, em função do escopo de nosso trabalho, analisaremos mais a fundo o impacto destes nas Jornadas de Junho. Não pretendemos, naturalmente, deixar de fora os outros dois fatores, apenas não os trabalharemos com a mesma profundidade.

Quando nos referimos ao "lulismo", termo cunhado por André Singer e que, como lembra Bruno Cava, consiste em "fenômeno de realinhamento eleitoral ocorrido no Brasil durante o governo Lula (2003 2010) inaugurando um ciclo de longa duração. Está se referindo à migração eleitoral massiva de eleitores mais pobres, no sentido da direita 
(principalmente a socialdemocracia, PSDB) para a esquerda (o PT) do espectro ideológico partidário" ${ }^{\$ 85}$.

Para Cava, este processo se apoiava em dois eixos: a massificação das políticas de inclusão social, que culminaram com a formação da chamada "Nova Classe Média" 86 e na superação do que chama de "chantagem do medo", arma utilizada pelos meios de mídia para conter a esquerda no país e que foi conseguida através da "domesticação" da esquerda mobilizada e também dos compromissos constituintes da Carta aos Brasileiros.

Foi Giuseppe $\operatorname{Cocco}^{87}$ quem percebeu a existência de um paradoxo no interior deste processo, causado pela existência de um pacto conservador para a "governabilidade", o qual não alterou em nada as estruturas da sociedade brasileira, por um lado e, por outro, da abertura de uma "brecha constituinte" por meio das políticas sociais de inclusão, a qual fez surgir novos sujeitos produtivos que alteraram de forma significativa a composição social.

A mera inclusão econômica já não era o suficiente para os membros dessa nova classe ${ }^{88}$. Ainda assim, a dimensão constituinte do lulismo foi ignorada pela esquerda no poder, processo intensificado com a posse de Dilma em 2011 e a investida do governo em uma economia

\footnotetext{
${ }^{85}$ CAVA, Bruno. A Cidade da Peste e seus carnavais. CAVA, Bruno; COCCO, Giuseppe (org.). Amanhã vai ser maior: O levante da multidão no ano que não terminou. $1^{\mathrm{a}}$ ed. Annablume: São Paulo, 2014. p. 370.

${ }^{86}$ Para uma crítica acerca das limitações da Nova Classe Média enquanto conceito de classe, recomendamos a leitura do prefácio de Giuseppe Cocco ao livro Trabalho Imaterial (Lazzarato e Negri). Daí, tiramos que, com o advento do capitalismo cognitivo e a ascenção do trabalho imaterial como forma hegemônica de trabalho, entra em jogo uma precarização de todas as formas de trabalho, reduzindo a segurança dos trabalhadores e aumentando a sua mobilidade no emprego. Para ele, o conceito de Nova Classe Média esta ultrapassado por se basear em um conceito de capitalismo que não é compatível com o atual estado do desenvolvimento deste sistema.

${ }^{87}$ COCCO, Giuseppe. Nova classe média ou nova concepção de classe. In: Revista Lugar Comum, $\mathrm{n}^{\mathrm{o}}$ 40. dez. 2013.

${ }^{88}$ Nas palavras de Adriano Pilatti e Giuseppe Cocco: “A garatia de direitos mínimos não aplaca o poder constituinte, antes desencadeia uma lógica expansiva das lutas que vão além da ascensão a uma pobreza menos penosa garantida pelo Estado".

COCCO, Giuseppe; PILATTI, Adriano. Quem tem medo do poder constituinte? In: Redes, Poder e Democracia no século XXI. WU, Vinicius (org.). Porto Alegre: Sapiens, 2013. p. 199.
} 
neodesenvolvimentista que tinha como objetivos fundamentais modernizar a economia, aumentar o emprego formal e a industrialização do Brasil.

Com a progressão do governo Dilma, há um descolamento cada vez maior entre o PT e as forças sobre as quais o lulismo se baseava. Com efeito, o governo adere de vez ao pacto conservador, deixando de lado a potência constituinte que havia se formado ao longo do governo Lula o que, a longo prazo, gera uma saturação deste processo político, a qual resulta com a erupção do movimento de junho de 2013. Fazemos a ressalva que quando citamos as repercussões negativas do lulismo, fazemos nossa análise a partir de uma perspectiva econômica e não necessariamente política. De fato, apesar de tudo, o PT continuou forte entre alguns setores da sociedade - sobretudo ligados à esquerda mais tradicional - mantendo grande apoio popular, embora evidentemente não tão grande quanto aquele que desfrutou durante seu auge.

Somando-se a esse desgaste, há aquele naturalmente causado pelas limitações, cada vez mais tensionadas, do sistema representativo tradicional. Tradicionalmente, na ciência política, entende-se que a soberania somente se aplica sobre o uno. Por este motivo, "traduz-se" a multidão em povo, anulando-se as suas singularidades, de forma a acomodar o exercício de um poder soberano sobre a população.

Todavia, conforme já analisado, com o advento do capitalismo cognitivo a multidão ressurge enquanto sujeito. O resultado prático deste fenômeno é o desgaste das estruturas burocráticas ${ }^{89}$ e administrativas dos Estados. O descontentamento resultante deste fato se materializou nas

\footnotetext{
${ }^{89}$ Quando nos referimos à burocracia, o fazemos como Rudá Ricci e Patrick Arley, quando dizem que: "A estrutura organizacional clássica do mundo moderno é a burocracia. Estrutura verticalizada em que todos os espaços no interior da organização são ocupados e possuem uma funcionalidade para saúde e ação do todo". Os autores, embora tenham identificado o desgaste das estruturas burocráticas estatais como uma das causas das Jornadas de Junho - e também de insatisfação ao redor do mundo, não a relacionam com o surgimento de outra classe nas relações sociais, no caso a multidão.

RICCI, Rudá; ARLEY, Patrick. Nas Ruas: A outra política que emergiu em junho de 2013. Belo Horizonte: Editora Letramento, 2014. p. 209.
} 
jornadas de junho por meio da recusa de todas as formas institucionalizadas de representação, inclusive a dos próprios partidos, cujos membros identificados chegaram até mesmo a ser expulsos de algumas manifestações.

Após uma brevíssima análise dos dois fatores antecedentes iremos, conforme exposto em nossa introdução, abordar o foco deste estudo que são os megaeventos. Primeiramente, devemos apresentar uma definição do que são os Megaeventos: como o próprio nome indica, tratam-se de eventos de proporções colossais. Congregam simultaneamente milhões de pessoas no mesmo local em torno de uma finalidade específica - tipicamente desportiva, casos das Copas da Confederação e do Mundo e das Olimpíadas, mas também podem ter outros propósitos, como a Jornada Mundial da Juventude, organizada pela Igreja Católica e que reuniu expressivo contingente de pessoas na cidade do Rio de Janeiro.

Cumpre ressaltar que embora tenhamos utilizado os dados mais recentes disponíveis, nossa análise de conjuntura também se aplica aos protestos de 2013, uma vez que não consideramos somente os resultados finais mas também os processsos que a eles conduziram e que se desdobraram durante anos no país.

Uma parte importante do discurso em torno dos Megaeventos - e que e que serve para dar legitimidade ao projeto de apropriação que estes trazem - é o chamado "legado" que em tese será deixado para as cidadessede. Tratam-se de benefício que extrapolam o escopo do evento em si - no caso das Olimpíadas, por exemplo, diziam-se que as benesses não se limitariam às novas arenas construídas, mas também a uma série de obras de infraestrutura e de repaginação da cidade, seguindo o "modelo Barcelona" 90 .

\footnotetext{
${ }^{90}$ As obras feitas para as Olimpíadas de 1992 repaginaram a capital catalã, tornando-a mais atrativa para turistas. Por este motivo, ela é considerada como um exemplo e referência para as demais cidades que desejam sediar os jogos.
} 
Usualmente, este discurso se estrutura em dois eixos: (i) no eixo material, as obras feitas para acomodar os participantes, sobretudo de infraestrutura, serviriam para tornar a cidade mais agradável e funcional para os seus habitantes e (ii) sobre um eixo simbólico, propaga-se que sediar um evento desse porte tornará a cidade mais reconhecida no exterior, o que atrairia mais turistas e também reverteria em benefícios financeiros. Ou, nas palavras de John Horne:

No contexto da globalização neoliberal, os Estados-nação utilizam o esporte para diferentes fins não desportivos: desenvolvimento econômico, desenvolvimento social, construção nacional, construção da marca nação e apoio na liberalização econômica e política $^{91}$.

É importante lembrar, entretanto, que estes também se inserem em um contexto de cidades "mercadorias", em que há uma competição entre diferentes locais para atração de turistas, investimentos e outros - processo que por si só já constituiria apropriação da riqueza comumente produzida na urbe, frise-se.

Iniciaremos nossa análise pela valorização estética da cidade. Dentro deste contexto de cidades competitivas, a imagem é um dos ativos mais valiosos. Para isso, é necessário que a cidade mostre o que tem de melhor, mesmo que este "melhor" não corresponda, necessariamente, à realidade urbana, como forma de preparar melhor a cidade para enfrentar a "concorrência".

\footnotetext{
91 HORNE, John. A Construção dos BRICS por meio da construção de estádios: reflexões preliminares sobre os recentes e futuros megaeventos esportivos em quatro economias emergentes. In: SÁNCHEZ (org.). et al.. A Copa do Mundo e as Cidades: Políticas, Projetos e Resistências. Niterói: Editora UFF, p. 37.

Aliás, não é por acaso que muitos países ditos emergentes, ou que tenham necessidade de trabalhar a imagem no exterior tenham buscado sediar estes eventos recentemente como a China (Olimpíadas de 2008), a Rússia (Copa do Mundo de 2018) e o Qatar (Copa do Mundo de 2022).
} 
Entra em cena o conceito que Anne Marie Brouderoux chama de Potemkinismo $^{92}$ e que, para a autora, consiste na

manipulação de aparências para distorcer a realidade, especialmente a fim de retratar um maior nível de desenvolvimento (...) Potemkinismo não se limita a sugerir um desejo de mistificar por meio do disfarce da realidade, mas também denota um desejo de agradar, impressionar e satisfazer as expectativas, mesmo que se tenha de recorrer a algum artifício para fazê-10 ${ }^{93}$.

Por exemplo, nos Jogos Olimpícos, para impedir que a população mais pobre fosse vista intensamente durante os jogos, optou-se por concentrarem-se as atividades na Barra da Tijuca, bairro de alto nível e que ficou com a Vila Olímpica e também com a maior parte das arenas. Inclusive, conforme denúncia Walmyr Junior em artigo publicado no Jornal do Brasil" "barreiras acústicas" foram instaladas ao longo das vias expressas da cidade com o objetivo de impedir que os transeuntes vissem as favelas instaladas em suas margens.

Fazemos apenas a ressalva de que a promoção da imagem da cidade talvez não tenha tido o efeito planejado. Embora o evento tenha sido reconhecido como um sucesso, incidentes como a entrega de quartos da Vila Olímpica com atraso causaram desgaste na imagem da cidade. Além disso, outros problemas da cidade, como os altos índices de violência e a situação financeira delicada foram para os holofotes. O próprio prefeito da cidade, Eduardo Paes, em um raro momento de autocrítica, reconheceu em entrevista ao jornal britânico The Guardian que os Jogos Olímpicos foram

\footnotetext{
${ }^{92}$ Segundo a autora, o conceito possui este nome porque, quando a Czarina Catarina, a Grande, foi visitar a Criméia, o almirante Grigory Potemkin teria criado "cidades falsas" ao longo do trajeto percorrido pela ferrovia.

BROUDEHOUX, Anne Marie. A construção da imagem urbana orientada por grandes eventos: potemkinismo e a mídia periférica. SÁNCHEZ et all.. (orgs). A Copa do Mundo e as Cidades: Políticas, Projetos e Resistências. Niterói: Editora UFF.p. 22.

${ }_{93}$ I BROUDEHOUX, Anne Marie. A construção da imagem urbana orientada por grandes eventos: potemkinismo e a mídia periférica. SÁNCHEZ et all.. (orgs). A Copa do Mundo e as Cidades: Políticas, Projetos e Resistências. Niterói: Editora UFF.p. p. 22.

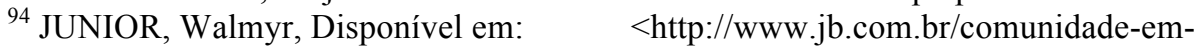
pauta/noticias/2016/07/18/esconderam-a-favela-com-adesivo-das-olimpiadas/>. Acesso em: 29 out. 2016.
} 
"uma oportunidade perdida" embora tenha, na ocasião, convenientemente atribuído a responsabilidade pelo fato a outros fatores ${ }^{95}$.

A partir deste discurso, buscou-se construir um "legado" para a cidade que, na verdade, foi de expropriação e de roubo da riqueza comum, revertida para o benefício de poucos, conforme indica o relatório feito pelo Comitê Popular Rio Copa e Olimpíadas.

O Comitê foi montado a partir da articulação de diferentes movimentos sociais, muitos com origem na luta pelo direito à moradia, na luta contra o modelo excludente dos megaeventos desportivos. Ele vem, desde a sua criação, elaborando periodicamente relatórios monitorando a situação destes e das populações por eles afetadas em diversas áreas como moradia e transporte. Estes relatórios, importante fonte de dados para os interessados na fiscalização dessas obras, são disponibilizados gratuitamente pela internet ${ }^{96}$.

Pretendemos aqui focar mais de perto nas questões de moradia e transporte público, por entendermos que são elas as que mais afetaram a vida dos habitantes da cidade e também por serem as áreas nas quais a expropriação se dá de forma mais clara.

$\mathrm{Na}$ questão da moradia, conforme disponibilizado pelo Comitê na última versão de seu relatório "22.059 famílias já [foram] removidas na cidade do Rio de Janeiro, totalizando cerca de 77.206 pessoas, entre 2009 e 2015, conforme dados apresentados pela Prefeitura do Rio de Janeiro em julho de $2015^{, 97}$.

Conforme o relatório aponta, os habitantes removidos - em geral localizados em regiões centrais da cidade - são sempre transferidos para locais periféricos, afastados do restante da cidade para imóveis

\footnotetext{
${ }^{95}$ Disponível em: <https://www.theguardian.com/cities/2016/jul/11/rio-mayor-eduardo-paes-2016olympics>. Acesso em: 29 out. 2016.

${ }^{96}$ Para obtê-los, basta acessar o site do Comitê. Disponível em: $<$ http://rio.portalpopulardacopa.org.br/?page_id=2972>.

${ }^{97}$ COMITÊ POPULAR RIO COPA E OLIMPÍADAS, 2015, p. 20.
} 
substancialmente mais baratos que os que habitavam ou então recebem indenizações em valores irrisórios e insuficientes para a aquisição de imóveis equivalentes.

Ressaltamos que a remoção de uma comunidade sempre implica também no desfazimento de toda uma teia de relacionamentos afetivos que nela é gestada. Essas trocas entre os habitantes constituem, com efeito, um comum produzido a partir do encontro das suas singularidades e que se perdem quando os habitantes são separados - o que é mais um motivo pelo qual esses processos em geral esbarram na resistência ferrenha dos moradores locais.

Muito emblemático foi o caso da Vila Autódromo, pequena comunidade que foi removida para a construção da Vila Olímpica. A retirada da comunidade já era um desejo antigo do prefeito da cidade do Rio, Eduardo Paes, que, na década de 90, quando era sub-prefeito da Barra da Tijuca, propôs ação pedindo a retirada da comunidade alegando danos morais e estéticos.

A sua remoção não era necessária, conforme restou claro pelo plano popular elaborado pela comunidade ${ }^{98}$ que provou era possível fazer uma Vila Olímpica integrada à comunidade, o que faria mais sentido diante da tradição de se deixar a habitação que os atletas usam durante os Jogos como moradia popular após a sua realização ${ }^{99}$.

A necessidade de isolar os pobres fica patente no discurso do dono da empreiteira responsável pelas obras que, sem o menor pudor, admitiu

\footnotetext{
${ }^{98}$ Para os interessados, segue aqui o link em que ele encontra-se disponível:

${ }^{99}$ Conforme dito por um dos porta-vozes da empreiteira que construiu em depoimento ao jornal "O Globo": A grande surpresa para os atletas será o fato de ser um conceito diferente das Olimpíadas anteriores. A proposta usual sempre foi fazer a Vila como um alojamento, uma coisa simples, como se fosse uma habitação popular, que depois vira um legado para o Estado vender de forma subsidiada para pessoas que necessitam de moradia. Aqui no Rio, foi dada a sugestão de oferecer uma Vila em uma localização melhor, perto do Parque Olímpico, com apartamentos mais confortáveis, condomínio estruturado, perto da praia e da lagoa, para as delegações verem aquilo que é o Rio. Não fazia sentido colocar a Vila na periferia".

ENGELKE, Antonio. O sentido do fracasso Olímpico. O Globo. 28 jul. 2016. Disponível em: $<$ http://oglobo.globo.com/opiniao/o-sentido-do-fracasso-olimpico-19797686\#ixzz4FmvhKpYg>. Acesso em: 28 jul. 2016.
} 
que estes não poderiam morar ali: "Para botar tubulação de água e de luz há um custo alto, e quem mora paga. Como é que você vai botar o pobre ali? Ele tem que morar perto porque presta serviço e ganha dinheiro com quem pode, mas você só deve botar ali quem pode, senão você estraga tudo, joga o dinheiro fora" 100 .

Mesmo os que mantiveram suas moradias foram afetados, uma vez que as obras e o grande fluxo de investimentos recebidos pela cidade causaram um grande aumento no custo de vida, puxado pela alta dos preços dos imóveis. Essa alta fez, inclusive, com que muitos fossem obrigados a deixarem suas casas em função dos preços, contribuindo para a gentrificação da cidade.

Conforme já estabelecemos em nosso primeiro capítulo, ao citarmos o exemplo das praças trazido por Mattei, o caráter comum de um determinado bem ou serviço advém do uso que lhe é atribuído pela população. Este é o caso do transporte público, que constitui um dos comuns urbanos e, que, no caso do Rio de Janeiro, foi manejado visando beneficiar as classes já favorecidas.

O transporte público no Rio de Janeiro, como é notório, está em um estado crítico, para não dizer trágico ${ }^{101}$. Por este motivo, visando melhor acomodar os turistas estrangeiros durante os jogos, vultuosas somas foram investidas em melhorias na infraestrutura de transporte da cidade, nem

\footnotetext{
${ }^{100}$ PUFF, Jefferson. Como é que você vai botar pobre ali? Diz bilionário "dono" da Barra da Tijuca. Disponível em:

$<$ http://www.bbc.com/portuguese/noticias/2015/08/150809_construtora_olimpiada_jp $>$. Acesso em: 12 nov. 2016.

${ }^{101}$ Mesmo com os investimentos dos últimos anos, segundo dados do relatório elaborado pelo Comitê em 2015: "O Rio de Janeiro continua tendo o maior tempo médio entre as principais regiões metropolitanas. Segundo dados da PNAD 2013, na Região Metropolitana do Rio de Janeiro (RMRJ), 29,4 \% da população trabalhadora leva mais de 1 hora no deslocamento casatrabalho, contra $25,4 \%$ de São Paulo. A RMRJ já tem uma frota superior a 3,2 milhões de automóveis e esse número segue aumentando, e parece que a implantação dos dois BRT's (Transoeste e Transcarioca) e dos BRS's não têm capacidade alguma de tirar das ruas os carros particulares, principais causadores dos congestionamentos".

COMITÊ POPULAR DA COPA E OLIMPÍADAS, Dossiê Megaeventos e Violações de Direitos Humanos no Rio de Janeiro Olimpíada Rio 2016: Jogos da Exclusão, pg. 46 Disponível em: $<\mathrm{https}$ ://comitepopulario.files.wordpress.com/2016/03/dossiecomiterio2015.pdf $>$. Acesso em: 29 out. 2016.
} 
sempre obtendo os resultados necessários, conforme aponta o relatório do Comitê Popular Rio Copa e Olimpíadas de 2015:

No caso da Transoeste, menos de um ano depois da inauguração da linha do BRT, sua infraestrutura começou a apresentar falhas, como mostrou a série de matérias jornalísticas que mostravam danificações no asfalto, queda de revestimento e infiltrações no túnel da Grota Funda, zona oeste, por onde passa o BRT ${ }^{102}$.

O traçado das obras também visa privilegiar os moradores das zonas mais abastadas. O melhor exemplo disso é a Linha 4 do Metrô que, apesar do nome, é apenas uma extensão da Linha 2, conectando Barra da Tijuca à Ipanema, passando por São Conrado, todos bairros de alto poder aquisitivo. A grande maioria dos habitantes das zonas mais pobres ficou excluída desse benefício. Tem-se aí, portanto, uma ação direta do poder público beneficiando as zonas mais ricas da cidade.

Concordamos com David Goldblatt, autor do livro The Olympic Games: A Global History of the Olympics, quando ele diz que:

Rio at least is not giving us the bother of having to wait a few years before we know whether its legacies have been successful or not, because so many of the most socially useful Olympic investments promised in the bid book have already been abandoned. While the rapid bus transit system and perhaps the metro are permanent legacies, both are primarily designed to ferry rich people between rich areas. The vast majority of the city's population in the Zona Norte, desperate for better transport to relieve their grindingly long journeys to work, will barely benefit at all ${ }^{103}$.

\footnotetext{
${ }^{102}$ COMITÊ POPULAR DA COPA E OLIMPÍADAS, Dossiê Megaeventos e Violações de Direitos Humanos no Rio de Janeiro Olimpíada Rio 2016: Jogos da Exclusão, pg. 45. Disponível em: $\quad<$ https://comitepopulario.files.wordpress.com/2016/03/dossiecomiterio2015.pdf $>$. Acesso em: 29 out. 2016.

103 “O Rio pelo menos não nos dá o trabalho de esperar alguns anos antes de saber se seus legados foram ou não bem sucedidos, porque a maioria dos investimentos Olímpicos mais benéficos à sociedade, prometidos em sua candidatura, já foram abandonados. Enquanto o Bus Rapid Transit (BRT) e talvez o metrô sejam legados permanentes, ambos foram originalmente projetados para transportar pessoas ricas entre áreas ricas. A grande maioria da população da cidade na Zona Norte, desesperada por melhores aternativas de transporte para aliviar suas extenuantes jornadas para o trabalho, serão pouquíssimo beneficiadas.

GOLDBLATT, David. Rio 2016 buildup part of the chaotic and corrupt tradition of Olympic hosts. Disponível em: <https://www.theguardian.com/sport/blog/2016/jul/26/buildup-rio2016-olympic-games-chaotic-hosts>. Acesso em: 28 out. 2016.
} 
Em um movimento no qual estiveram presentes intensos sentimentos de recusa às instituições governamentais, era esperado que os mesmos participassem do processo de apropriação observado. Com efeito, e seguindo o corolário já estabelecido segundo o qual, no sistema capitalista, público e privado se unem pela predação do comum, o Estado teve intensa participação nos processos acima descritos.

Além da "farra" das indenizações - que renderam ao estado do Rio de Janeiro uma das maiores crises de sua história e um pedido de calamidade pública - e dos favorecimentos ilícitos que agora veem à tona, a atuação estatal foi observada por meio da adequação da legislação brasileira aos fins visados por estes eventos. do grande capital.

Embora não seja o objetivo de nosso trabalho analisar essas leis, não podemos deixar de citar, como exemplo, a Lei Geral da Copa, ou Lei 12.663/2012, nas palavras de Nelma Oliveira e Carlos Vainer:

trata-se de estabelecer exceções à ordem jurídica vigente para quatro situações especiais relacionadas à Copa do Mundo de 2014 e à Copa das Confederações de 2013: proteção e exploração dos direitos comerciais relacionados ao evento; flexibilidade na concessão dos vistos de entrada e permissão de trabalho no país; responsabilidade civil da União sobre os danos causados à FIFA ou a terceiros durante a preparação; e, finalmente, realização do evento e a venda de ingressos ${ }^{104}$.

À época de sua promulgação, o projeto chamou mais atenção em função da restrição de vendas e circulação no entorno dos estádios, inclusive com a polêmica tentativa da FIFA de tentar proibir a venda de acarajés nos arredores do Estádio da Fonte Nova (da qual a entidade foi forçada a desistir após intensa reação popular ${ }^{105}$ e que teve como base o artigo 11 da Lei Geral da Copa cuja redação, conforme se vê abaixo, veda

\footnotetext{
${ }^{104}$ VAINER, Carlos; OLIVEIRA, Nelma Gusmão. Megaeventos no Brasil e no Rio de Janeiro: Uma articulação transescalar na produção da cidade de exceção. In: SÁNCHEZ et al.. (org). $A$ Copa do Mundo e as Cidades: Políticas, Projetos e Resistências. Niterói: Editora UFF, p. 101.

105 Disponível em: http://g1.globo.com/bom-dia-brasil/noticia/2013/06/fifa-libera-venda-deacaraje-nos-jogos-da-arena-fonte-nova-em-sa.html, acessado no dia 29/10/2016.
} 
expressamente o comércio no entorno dos estádios que recebem jogos da Copa:

Art. 11. A União colaborará com os Estados, o Distrito Federal e os Municípios que sediarão os Eventos e com as demais autoridades competentes para assegurar à FIFA e às pessoas por ela indicadas a autorização para, com exclusividade, divulgar suas marcas, distribuir, vender, dar publicidade ou realizar propaganda de produtos e serviços, bem como outras atividades promocionais ou de comércio de rua, nos Locais Oficiais de Competição, nas suas imediações e principais vias de acesso.

$\S 1^{\circ}$ Os limites das áreas de exclusividade relacionadas aos Locais Oficiais de Competição serão tempestivamente estabelecidos pela autoridade competente, considerados os requerimentos da FIFA ou de terceiros por ela indicados, atendidos os requisitos desta Lei e observado o perímetro máximo de $2 \mathrm{~km}$ (dois quilômetros) ao redor dos referidos Locais Oficiais de Competição.

$\S 2^{\underline{0}}$ A delimitação das áreas de exclusividade relacionadas aos Locais Oficiais de Competição não prejudicará as atividades dos estabelecimentos regularmente em funcionamento, desde que sem qualquer forma de associação aos Eventos e observado o disposto no art. 170 da Constituição Federal (Grifo nosso)

A necessidade de garantir a exclusividade do comércio se dá em função do modelo adotado para tornar lucrativos estes megaeventos. Com algumas pequenas diferenças, a FIFA e o COI adotam modelos muito similares: apostam na transmissão maciça dos eventos e na união com poucos parceiros que, em troca de grandes valores investidos, recebem não só exclusividade para patrocinar os eventos como também para comercializar durante eles, garantindo gordas fatias de lucro para os organizadores e também para as sedes. Como o COI e a FIFA são detentores dos eventos, acabam fazendo com que as sedes precisem adotar este tipo de medida.

Além disso, também foram muito polêmicas as modificações no Estatuto do Torcedor permitindo o consumo de bebida alcóolica nos estádios durante os eventos da FIFA, o que a época era vedado pela legislação nacional. Ressalta-se que tal medida era necessária para agradar uma das patrocinadoras da FIFA que comercializa bebidas alcoólicas e que, portanto, precisaria que fosse permitido o comércio de sua cerveja nos 
estádios para garantir o seu lucro durante a competição. A longo prazo, isto acabou resultando na alteração dos próprios dispositivos do estatuto do torcedor para que a possibilidade de se beber durante os jogos de futebol vigorasse o ano todo.

O cenário que se vivia em 2013 está, portanto, armado. Por trás de uma calmaria aparente, uma multidão indignada preparava-se para irromper, nas ruas, em torno das defesa dos comuns e contra "tudo o que está aí."

\subsection{J-13: 0 rugido da plebe}

A gota da água para a eclosão do movimento multitudinário foi o transporte público. Desde de março de 2013 vinte centavos. Foi um aumento de apenas vinte centavos nas passagens que serviu como o detonador de todo um movimento que, durante meses, abalou o país. Embora revoltas causadas pelo transporte público não sejam exatamente novidade no Brasil, e em especial no Rio de Janeiro, vide a histórica "Revolta do Vintém ${ }^{106 ",}$, estes se eternizariam por sua intensidade e por seu tamanho, reunindo milhões de pessoas nas ruas.

A mobilidade urbana é uma questão crítica nas grandes cidades brasileiras. Passa-se cada vez mais horas no trânsito e em condições cada vez mais precárias. O transporte público de qualidade constitui não só um comum urbano como é condição essencial para que seja garantido, em sua plenitude, o acesso à cidade.

As manifestações começaram de forma muito tímida, a partir de atos convocados pelo Movimento Passe Livre ${ }^{107}$ (MPL) contra o aumento das passagens em São Paulo. O cenário começou a mudar na manifestação

\footnotetext{
${ }^{106}$ Trata-se de uma revolta histórica ocorrida no Rio de Janeiro no final do século XIX, na qual os habitantes da cidade, então capital do Império, sublevaram-se contra a cobrança de um tributo de vinte réis - ou um vintém, daí o nome da revolta - sobre as passagens dos bondes.

${ }^{107}$ O Movimento Passe Livre é um coletivo que tem como principal bandeira a luta pelo transporte público gratuito.
} 
convocada pelo MPL no dia 13 de junho de 2013. A intensa violência policial enfrentada pelos manifestantes atuou como um catalizador dos protestos, conforme veremos adiante. nos processos. $\mathrm{O}$ repúdio à violência faz com que sejam convocadas manifestações em todo o país, em solidariedade ao ato de São Paulo ${ }^{108}$. A partir daí, o MPL também passa a perder o protagonismo nas convocações dos atos, os quais começam a ser chamados de forma descentralizada por diversas pessoas nos mais diferentes cantos do país.

Esse mudança ficou bem registrada por Bruno Cava, quando ele diz que:

\begin{abstract}
A indignação extravasou a questão da tarifa zero, no campo estratégico dos transportes públicos, e contaminou praticamente todos os fóruns e redes ativistas, transformando-as e produzindo novas. Passou-se a contestar o modelo de democracia, de comunicação, e de representação, o direito à cidade - agendas mais alargadas, mas nem por isso menos concretas e urgentes, reconhecíveis pelas pessoas. Não era mais, neste ciclo, uma luta meramente contra a privatização, o mercado ou o neoliberalismo, como nas décadas passadas, segundo o modelo dicotômico público x privado, - mas uma luta multitudinária que foi diretamente ao coração do público, que não distingue entre estado e mercado, entre a burocracia e o aglomerado de interesses empresariais, financeiros e mafiosos (três interesses que, no fundo, é o mesmo) que também e sobretudo são estado"109.
\end{abstract}

Tem-se na descentralização, observada na perda de protagonismo do MPL, na difusão das pautas e na sua interconectividade os primeiros elementos que caractetizam as Jornadas de Junho como evento da multidão.

No Rio, a repressão policial serviu para incitar o comparecimento maciço das pessoas nas ruas, assim como no restante do país. Manifestações foram sendo marcadas como forma de protesto e também de mostrar solidariedade com as vítimas da agressão policial. No dia 17 de junho,

\footnotetext{
108 "Até então, a grande mídia estava ignorando a repressão policial, mas centenas de cidadão registravam em tempo real com seus celulares o uso abusivo do gás lacrimogéneo e balas de borracha. A raiva explode. $\mathrm{O}$ dia 13 foi o ponto da virada. $\mathrm{O}$ rumo da onda de protestos que começou com o primeiro ato do MPL (06 de junho) havia mudado".

MORAES, Alana et al.. Junho: potência das ruas e das redes. $1^{\text {a }}$ ed. São Paulo: Friedrich, Ebert, Stiftung, 2014. p. 12.

${ }^{109}$ CAVA, Bruno. A multidão foi ao deserto: as manifestações no Brasil em 2013. $1^{\text {a }}$ ed. São Paulo: Annablume, 2013. p. 15.
} 
manifesatntes tentaram invadir a Assembleia Legislativa do Rio de Janeiro, o que atiçou ainda mais a repressão aos manifestantes. No dia 20 de junho, tivemos a maior das manifestações daquele ciclo, reunindo pelo menos um milhão de pessoas na Candelária, que foi um dos marcos mais importantes deste processo.

A partir daí, intensificou-se a repressão ainda mais - tanto que não houve mais nenhuma manifestação tão grande neste ciclo ${ }^{110}$ - e também a tentativa, falha, de captura do movimento pela direita - o que justificou a desqualificação dos manifestantes como "coxinhas".

No dia 25 de junho, centenas de moradores de favelas desceram de seus morros para protestar na zona sul carioca. O que foi, na época, anunciado como um pretexto para vandalismos e arrastões mostrou-se verdadeira aula de civilidade. Ao final do ato, os manifestantes reuniram-se com os membros da "Ocupa Cabral", ocupação montada na esquida da Avenida Delfim Moreira com a Rua Aristídes Espíndola, no Leblon, perto da casa do então governador do Rio de Janeiro, Sérgio Cabral, como forma de cobrar a sua renúncia ao cargo.

As ocupações são um tipo de protesto muito singular, uma vez que elas ressignificam o espaço outrora tido como público, através da produção de afetos e da interação entre as singularidades de seus habitantes, tornando-o comum. Vê -se aí mais um dos elementos caracteristícos da multidão: a produtividade, voltada para o comum. Adriano Pilatti assim descreve o Ocupa Cabral e seus membros:

\footnotetext{
110 “O estrago da repressão policial estava feito. Sua avassaladora truculência teve um claro intento de intimidação e produziu um forte efeito dissuasivo, facilitado pela ênfase dada pelos meios de comunicação aos confrontos violentos e pelo próprio êxito da luta contra o aumento das passagens."

In PILATTI, Adriano; O ano das maravilhas e do pesadelo, publicado em COCCO, Giuseppe e CAVA, Bruno (org.) Amanhã vai ser maior: O levante da multidão no ano que não terminou. $1^{\mathrm{a}}$ ed. Annablume: São Paulo, 2014.
} 
"pude testemunhar ali um experimento fecundo de cooperação na diversidade e de horizontalidade na organização. Jovens militantes pertencentes a vários grupos anarquistas, socialistas, comunistas e militantes autônomos se congregavam num processo absolutamente democrático de decisões sobre alimentação, abrigo, limpeza, normas de convivência. E desenvolviam iniciativas como a realização de aulas (a primeira delas ao meu encargo, graças a generoso convite deles), debates, projeções, palestras, atividades para crianças, shows, performances, exposição de desenhos e pinutras, além de um renovar-se de cartazes em que seus pensamentos, exigências e questionamentos se expressavam continuamente: 'onde está o Amarildo?'; 'a máscrara nos protege da repressão política'; 'a única luta que se perde é a que se abandona. ${ }^{111}$,"

Conforme vemos acima, as ocupações são um rico experimento do comum, dotados de grande dimensão constituinte, o que só é possível em função da potência da multidão. Além disso, observamos nos jovens que participam deste tipo de manifestação, uma radical opção pela igualdade e pela democracia na sua forma mais absoluta - todas as decisões são tomadas em assembleias, nas quais todos os membros possuem voz igual e participam diretamente, sem precisarem recorrer à armadilha da representação.

Um dos marcos daqueles meses foi o desaparecimento de Amarildo, pedreiro e morador da Rocinha. Embora muitos desapareçam em circunstâncias iguais - eliminados pelo estado por meio da truculência policial - o caso dele tornou-se pauta da multidão nas ruas, uma vez que muitos dos que estiveram presentes também eram das zonas mais pobres da cidade e também sofriam cotidianamente com a violência policial.

Os manifestantes, todavia, encontraram uma violenta reação pela frente, vinda de todos os lados: da direita, esquerda e também dos governos

\footnotetext{
111 In PILATTI, Adriano; O ano das maravilhas e do pesadelo, publicado em COCCO, Giuseppe e CAVA, Bruno (org.) Amanhã vai ser maior: O levante da multidão no ano que não terminou. $1^{\mathrm{a}}$ ed. Annablume: São Paulo, 2014.
} 
- inclusive do governo federal, que sempre agiu de forma contundente em apoio a repressão ${ }^{112}$. Não obstante a gravidade dos atos perpetrados pelo Estado, é de se ressaltar que a atitude violenta das autoridades já era esperada.

Isso porque, como lembra Negri, no Império a exceção é a regra e a política passa a se tornar uma continuidade da guerra. $\mathrm{O}$ uso da violência se torna legitimado a partir dos fatos concretos. Nas Jornadas de Junho, presenciamos uma ameaça à soberania, o que fez com que o poder constituído usasse de violência para conter a erupção do poder constituinte nas ruas.

Foi montado um sofisticado aparato repressivo para sufocar a voz das ruas, com base na adoção de diversas leis com caráter repressivo, visando impedir eventuais manifestações.

Além disso, destacamos a aplicação da lei do 12.850/2013, a lei do crime organizado, contra manifestantes, com o objetivo de: (i) desarticular os movimentos na ruas e (ii) privar os manifestantes de seus direitos. Com efeito, a referida lei prevê uma série de medidas que poderiam ser ditas de “exceção" e que tornam mais difícil a defesa dos manifestantes.

No Rio de Janeiro, especificamente, tivemos um episódio marcante no âmbito da repressão ao direito de manifestação, que foi a criação da Comissão Especial de Investigação de Atos de Vandalismo em Manifestações (CEIV) pelo então governador Sérgio Cabral. A Comissão operava com plenos poderes para investigar e devassar a vida pessoal de qualquer manifestante - ou pessoa suspeita de envolvimento em manifestações.

\footnotetext{
112 Até mesmo Gilberto Carvalho, então um dos homens fortes do governo Dilma, reconheceu a dificuldade de diálogo da presidente com a sociedade. BBC. Entrevista. Disponível em:

$<$ http://www.bbc.com/portuguese/noticias/2014/11/141108_entrevista_gilberto_jf_fd $>$. Acesso em:
} 
Sobre estes expedientes legais ${ }^{113}$, disse o juiz João Batista Damasceno, em artigo publicado na revista Fórum, que:

A criminalização dos movimentos sociais no presente momento é cabal demonstração de que as autoridades pretendem se reforçar pelo uso da força, por não disporem dos meios de convencimento dos cidadãos (...) na falta de outro tipo no qual se enquadrar, optou pelo indiciamento de 'formação de quadrilha'. Mas a manifestação coletiva não expressa associação. Menos ainda que seja associação para o cometimento de crimes. O direito de manifestação do pensamento é constitucional. O que a CEIV, integrada pelo MP, buscou apurar não foram os crimes. Não se tem notícia de apuração dos abusos policiais. O que se buscou foi intimidar a sociedade ${ }^{114}$.

No campo extra-legal, tornou-se comum acompanhar a arbitrariedade das polícias militares - fato que transformou a desmilitarização da polícia em pauta dos protestos - como espancamentos, uso de armas não-letais contra os manifestantes, o confisco do vinagre, usado pelos manifestantes para neutralizar os efeitos do gás lacrimogênio, transferência de delegacias, de forma a dificultar o exercício do trabalho dos advogados e também as "prisões em massa" que os policiais realizavam durante os protestos, das quais a maior vítima foi certamente Rafael Braga, que tornou-se símbolo do arbítrio estatal ao ser preso pelo porte de Pinho Sol. Recentemente, ele conseguiu liberdade condicional, mas foi novamente preso, desta vez por comprar pão.

O avanço da violência, entretanto, conforme já falamos acima, não foi capaz deter o avanço das manifestações que, como cita Bruno Cava, se alastravam como uma "peste ${ }^{115 "}$. A multidão buscou formas de defesa que,

\footnotetext{
113 Não fazemos aqui apologia à licitude ou constitucionalidade das leis citadas, até porque acreditamos que elas não estão em consonância com o direito brasileiro, mas sim de uma referêcnia ao meio escolhido: como a repressão se deu através da edição de novas leis, optamos por chamá-la de uma repressão "legal".

${ }^{114}$ DAMASCENO, João Batista. In: Revista Fórum, no 11, ano 33, p. 24.

${ }^{115}$ In CAVA, Bruno, A Cidadade da Peste e seus Carnavais em COCCO, Giuseppe e CAVA, Bruno (org.) Amanhã vai ser maior: O levante da multidão no ano que não terminou. $1^{\text {a }}$ ed. Annablume: São Paulo, 2014.

A peste, para o autor, é "a descrição de um processo político capaz de alimentar-se de antagonismos prévios e tensões sociais, para conquistar todo efeito de escala e terminar por investir a cidade como um todo, em seu desejo de revolta e recriação. O perigo da peste é também sua delícia: a incapacidade de ser controlada de fora, a sua absoluta imanência com os corpos e mentes que formam a cidade". Para chegar neste conceito, ele parte da explicação que Foucault da
} 
nas ruas, se cristalizaram a partir praticantes da tática black block, criada na Alemanha da década de 80 como forma de proteger os manifestantes de confrontos diretos contra a polícia ${ }^{116}$.

No Brasil, os adeptos da tática black block ficaram rapidamente marcados como violentos, agressivos e vândalos posto que, além de revidarem a agressão policial, eles também praticavam violência contra os símbolos do capitalismo, por vezes quebrando carros e vidraças de banco.

Embora a grande mídia tenha avançado sobre os adeptos da tática, acusando-os de ser um grupo terrorista e inclusive de agirem visando “deslegitimar" as passeatas pacíficas dos "manifestantes", o black block se consolidou no contexto das manifestações de junho - é o que Cava chama de vitória do devir black - e continuaram a atuar politicamente, ainda que sob intensa repressão do Estado, que chegou até mesmo a tornar ilegal o uso de máscaras em manifestações.

O Estado não foi o único a se levantar contra os black blocks. De fato, não tardou para começarem a pipocar acusações de "fascismo" contra os membros do grupo, partindo de diferentes direções. Talvez a mais grave delas, e que não deve ser omitida, tenha sido a proferida pela professora da USP Marilena Chaú que, em palestra à Polícia Militar do Rio de Janeiro, afirmou que os black blocks agiam com "inspiração fascista ${ }^{117}$ ". Como se a Polícia Militar do Rio precisasse justificativas para agredir os manifestantes.

Ainda assim, algumas vozes se levantaram em defesa dos black blocks e também dos direitos fundamentais. Conforme lembrou o professor Adriano Pilatti em entrevista ao IHU Unisinos

para a diferença política entre a lepra e a peste: a primeira representando a exclusão e a segunda representando a vigilância e também em Artaud, que diz que a dimensão espiritual da peste seria a de um "acontecimento deflagrador para uma nova realidade na cidade".

${ }^{116}$ SANTOS. Mariana Corrêa dos . Corpos em Movimento: Black Block Carioca e Representações de Resistência. Amanhã vai ser maior: O levante da multidão no ano que não terminou. $1^{\mathrm{a}} \mathrm{ed}$. Annablume: São Paulo, 2014.

117 Disponível em: <http://www1.folha.uol.com.br/fsp/poder/126068-black-blocs-agem-cominspiracao-fascista-diz-filosofa-a-pms-do-rio.shtml>. 
“eles querem ser cidadãos e são satanizados pura e simplesmente porque põem uma máscara no rosto, independentemente do que fizerem ou deixarem de fazer. O que poucos sabem é que, para muitos deles, que vivem em territórios onde os direitos civis não chegaram, territórios controlados por milícias, traficantes, etc., a máscara é um recurso de autodefesa sem o qual seriam perseguidos ao retornarem para casa, ou perderiam seus empregos, porque muitos trabalham para os seus territórios de origem, onde os direitos civis não chegaram. $\mathrm{O}$ enunciado 'se usa máscara, então faz vandalismo' é falso" ${ }^{\text {"118. }}$.

\section{Além disso, conforme disse o professor em palestra proferida no IAB, a origem social dos manifestantes também pesou contra eles na avaliação do uso da violência. Com efeito, diz ele que:}

Se há uma lei imutável no processo histórico brasileiro, desde 1500 até hoje, do Massacre dos Tamoios a Palmares, de Canudos ao Contestado, é lei não escrita segundo a qual nenhuma violência vinda de baixo será jamais tolerada ${ }^{119}$.

Apesar da violência, a multidão não esmoreceu. Permaneceu firme na luta e a semente daquilo que foi plantado em 2013 permanece viva ainda hoje. Embora passados três anos os tremores de junho ainda se fazem sentir no solo brasileiro. A "peste” alastrou-se pela sociedade de forma rápida e já se pode arriscar dizer que não será curada tão cedo, deixando um rico aprendizado de vivência em comum.

\footnotetext{
118 PILATTI, Adriano. Entrevista ao IHU Unisinos. Disponível em: $<$ http://www.ihu.unisinos.br/entrevistas/525872-o-regime-militar-nao-acabou-nas-periferias- $>$. Acesso em: 22/10/2016.

Além da proteção, Pilatti, em palestra proferida no IAB, também cita um interessante fenômeno de ressignificação do uso da máscara. Para o professor, ao colocarem a máscara, os manifestantes mais pobres deixam a invisibilidade de sua condição social para tornarem-se visíveis perante a sociedade.

119 Palestra proferida pelo professor Adriano Pilatti, da PUC-Rio, em seminário no IAB e compilada no livro "Manifestações de Junho de 2013: Avanços e Retrocessos um ano depois".
} 


\section{CONCLUSÃO}

Ao longo de nosso trabalho, apresentamos as noções de comum e bens comuns, poder constituinte e multidão e buscamos relacioná-las com os levantes juninos que tomaram de assalto o país. Acreditamos ter conseguido atingir o nosso intento, tendo demonstrado como as jornadas de junho se enquadram no novo ciclo global de lutas pelo comum.

Se não foram inteiramente vencedores, os jovens rebeldes que tomaram as ruas brasileiras em junho de 2013 conquistaram um número expressivo de vitórias. Todavia, não devem deixar-se iludir pelos resultados obtidos: o assalto ao comum intensifica-se cada vez mais no mundo todo.

Ainda assim, podemos dizer que o movimento que eclodiu no Brasil foi, de fato, vitorioso. Pretendemos aqui, portanto, discorrer sobre os motivos que nos levam a fazer esta afirmação.

Em primeiro lugar, recordamos que os manifestantes conseguiram vetar o aumento dos preços das passagens de ônibus. Com efeito, após o movimento ter se alastrado, diversos prefeitos vieram a público para voltar atrás, visando impedir o prosseguimento dos movimentos, em uma espécie de mediação fracassada com aqueles que estavam nas ruas.

Especificamente, no Rio de Janeiro, não podemos deixar de citar uma "vitória moral" dos que contestavam o modelo exploratório dos megaeventos e seu impacto negativo na cidade. Com efeito, recentemente vieram à tona diversos escândalos de corrupção envolvendo as obras para receber a Copa do Mundo e as Olimpíadas, que dão razão ao grito do "Não vai ter Copa".

Falando ainda sobre os megaeventos, não podemos deixar de destacar o Maracanã ${ }^{120}$ como uma vitória, ainda que parcial. Com efeito, o

\footnotetext{
${ }^{120}$ O Estádio do Maracanã é um comum, produzido através do trabalho dos milhares de corpos em sua grande maioria pobres - que frequentaram o estádio por décadas. Com efeito, até o nome pelo qual ele é conhecido (Maracanã) foi dado pela multidão.
} 
estádio foi entregue à iniciativa privada após quase um bilhão de gastos em reformas ao longo de 10 anos - feitas para o Mundial da FIFA de 2000, os Jogos Pan Americanos de 2007 e a Copa do Mundo de 2014 - praticamente de graça.

Como se isso já não bastasse, o consórcio que administraria o estádio decidiu demolir seu entorno - no qual se encontram a melhor escola municipal do Rio, a Aldeia Maracanã, antigo Museu do Índio, o Parque Aquático Julio Dellamare e a pista de atletismo Célio de Barros - para a construção de um shopping center com estacionamento, seguindo o modelo das modernas arenas européias.

Todavia, a intensidade do movimento que eclodiu nas ruas fez com que o consórcio voltasse atrás. Eventualmente, essa decisão levou à impossibilidade financeira de operar o estádio, devido aos altos custos de manutenção e ao baixo retorno financeiro, o que fez com que a concessão fosse devolvida ao estado do Rio de Janeiro.

Além disso, recentemente a ALERJ anunciou que foram obtidas as assinaturas necessárias para a abertura de uma CPI para investigar as obras do Maracanã, de onde espera-se que saíam novos dados que demonstrem a razão da revolta multitudinária.

Outro caso que não se pode deixar de citar é o do pedreiro Amarildo, que virou uma das principais pautas das manifestações após desaparecer na favela da Rocinha, onde morava. A busca pelo seu paradeiro tomou proporções gigantescas e reverberou também nas ruas, através do grito “Cadê o Amarildo?”, que transformou-se também em pauta de reivindicações ${ }^{121}$.

Embora não tenha sido achado com vida, é seguro dizer que o caso de Amarildo sequer teria sido investigado caso não existisse a pressão feita

\footnotetext{
${ }^{121}$ Observamos aqui que o paradeiro do Amarildo, como reivindicação, não é só o do pedreiro citado, mas também o das centeas de "Amarildos" que cotidianamente desaparecem sem explicação nas favelas país afora.
} 
pelas ruas, como o de tantos outros homens e mulheres que desaparecem pelas favelas país afora.

Por fim, acreditamos que o grande legado de Junho tenha sido incluir, de vez, o comum na pauta das manifestações, além de ter trazido novas formas de reivindicar, em especial as ocupações, que vem ocorrendo com cada vez mais força ${ }^{122}$.

Além disso, as Jornadas de Junho também tiveram um "aspecto pedagógico", uma espécie de "pedagogia da revolta", por assim dizer, uma vez que naqueles dias ficou claro que a resistência era possível e que se poderia sonhar com um mundo novo. Não por acaso, na esteira desse movimento o país observou a eclosão de outros, como a greve dos garis no Rio de Janeiro, que ocorrou contra o governo e contra o sindicato e mesmo de movimentos com objetivos ou formas diferentes, como os rolézinhos, todos alimentando-se do sonho surgido das ruas em 2013 e por ele influenciado.

A mensagem de Junho de 2013 é mais de esperança do que de medo. É a possibilidade real e concreta de uma mudança no ordenamento social com rumo a uma sociedade baseada no comum.

\footnotetext{
${ }^{122}$ No momento em que estas linhas são escritas, o país atravessa uma "onda" de ocupações de escolas e universidades, que atingiu inclusive a própria PUC-Rio.
} 


\section{REFERÊNCIAS BIBLIOGRÁFICAS}

BASTIDORES F.C. A Odebrecht pede oficialmente a recisão do contrato de concessão do Maracanã. Disponível em:

$<$ http://globoesporte.globo.com/blogs/especial-blog/bastidores-

fc/post/odebrecht-pede-oficialmente-rescisao-do-contrato-de-concessao-domaracana.html>. Acesso em: 29 jul. 2016.

BBC. Entrevista. Disponível em:

$<$ http://www.bbc.com/portuguese/noticias/2014/11/141108_entrevista_gilb erto_jf_fd $>$. Acesso em: 29 out. 2016...

BONAVIDES, Paulo. Ciência Politica. 19 ${ }^{\mathrm{a}}$ ed. São Paulo: Malheiros Editores, 2012.

BRASIL, Decreto No 3.897, de 24 de agosto de 2001. Disponível em: $<$ http://www.defesa.gov.br/arquivos/2014/mes02/md33_m_10_glo_2ed_20 14.pdf>. Acesso em: 29 out. 2016...

BRASIL, Lei $\mathrm{n}^{0} 12.462$ de 4 de agosto de 2011. Disponível em: $<$ http://www.planalto.gov.br/ccivil_03/_Ato20112014/2011/Lei/112462.htm>. Acesso em: 29 out. 2016...

BRASIL, Lei $\mathrm{n}^{\circ} 12.633$ de 5 de junho de 2012. Disponível em: $<$ http://www.planalto.gov.br/ccivil_03/_Ato2011-

2014/2012/Lei/L12663.htm>. Acesso em: 29 out. 2016.

BROUDEHOUX, Anne Marie. A construção da imagem urbana orientada por grandes eventos: potemkinismo e a mídia periférica. SÁNCHEZ et all. (orgs). A Copa do Mundo e as Cidades: Políticas, Projetos e Resistências. Niterói: Editora UFF.

CAVA, Bruno. A Cidade da Peste e seus carnavais. CAVA, Bruno; COCCO, Giuseppe (org.). Amanhã vai ser maior: O levante da multidão no ano que não terminou. $1^{\mathrm{a}}$ ed. Annablume: São Paulo, 2014.

CAVA, Bruno. A multidão foi ao deserto: as manifestações no Brasil em 2013. $1^{\text {a }}$ ed. São Paulo: Annablume, 2013. 
COCCO, Giuseppe; Nova classe média ou nova concepção de classe. In: Revista Lugar Comum, no 40. dez. 2013.

COMITÊ POPULAR DA COPA E OLIMPÍADAS, Dossiê Megaeventos e Violações de Direitos Humanos no Rio de Janeiro Olimpíada Rio 2016: Jogos da Exclusão. Disponível em:

$<$ https://comitepopulario.files.wordpress.com/2016/03/dossiecomiterio2015 .pdf>. Acesso em: 29 out. 2016.

COUTO DE CASTRO, Guilherme. Direito Civil: Lições $5^{\text {a }}$ ed. Niterói. Impetus.

DAMASCENO, João Batista. Entrevista. In: Revista Fórum, nº 11, ano 33.

Disponível em: <http://g1.globo.com/bom-dia-brasil/noticia/2013/06/fifalibera-venda-de-acaraje-nos-jogos-da-arena-fonte-nova-em-sa.html> . Acesso em: 29 out. 2016.

ENGELKE, Antonio. O sentido do fracasso Olímpico. O Globo. 28 jul. 2016. Disponível em: $\quad<$ http://oglobo.globo.com/opiniao/o-sentido-dofracasso-olimpico-19797686\#ixzz4FmvhKpYg>. Acesso em: 28 jul. 2016.

FACHIN, Patricia; PILATTI, Adriano (Ed.). A tipificação de crime de terrorismo no Brasil: A perversidade da lei é a sua própria criação. Entrevista especial com Adriano Pilatti. Revista Ihu Online. Rio de Janeiro, 02 mar. 2016. Disponível em:

$<\mathrm{http}$ ://www.ihu.unisinos.br/entrevistas/552134-a-perversidade-da-leiantiterrorismo-e-a-sua-propria-criacao-entrevista-especial-com-adrianopilatti>. Acesso em: 29 out. 2016.

FOLHA DE SÃO PAULO, Disponível em: $<$ http://www1.folha.uol.com.br/fsp/poder/126068-black-blocs-agem-cominspiracao-fascista-diz-filosofa-a-pms-do-rio.shtml $>$. Acesso em: 29 out. 2016.

GOLDBLATT, David. Rio 2016 buildup part of the chaotic and corrupt tradition of Olympic hosts. Disponível em:

$<$ https://www.theguardian.com/sport/blog/2016/jul/26/buildup-rio-2016olympic-games-chaotic-hosts>. Acesso em: 28 out. 2016.

GUIMARAENS, Francisco de. O poder constituinte na perspectiva de 
Antonio Negri: um convite muito além da modernidade hegemônica. $1^{\mathrm{a}}$ ed. Rio de Janeiro: Editora Forense, 2004.

HARDT, Michael; NEGRI, Antonio. Comune: oltre il privato e il publico. Alessandro Pandolf (trad.). $1^{\text {a }}$ ed. Milano: Rizzoli Libri, 2010.

HARDT, Michael; NEGRI, Antonio. Multidão: Guerra e Democracia na Era do Império. MARQUES, Clóvis (trad.). $2^{\mathrm{a}}$ ed. Editora Record, 2012.

HORNE, John. A Construção dos BRICS por meio da construção de estádios: reflexões preliminares sobre os recentes e futuros megaeventos esportivos em quatro economias emergentes. In: SÁNCHEZ (org.). et al.. $A$ Copa do Mundo e as Cidades: Políticas, Projetos e Resistências. Niterói: Editora UFF.

JUNIOR, Walmyr, Disponível em:

$<$ http://www.jb.com.br/comunidade-em-

pauta/noticias/2016/07/18/esconderam-a-favela-com-adesivo-das-

olimpiadas/>. Acesso em: 29 out. 2016.

KONDER, Komparato. Capitalismo e Poder. In: WU, Vinicius (org.). Redes, Poder e Democracia no século XXI. Porto Alegre: Sapiens, 2013.

LUCARELLI, Alberto. La democrazia dei beni comuni, 1.ed. Roma-Bari, Editora Laterza \& Figli Spa, 2013.

MACKAAY, Ejan; ROUSSEAU, Stéphane. Análise econômica do direito. SZTAJN, Rachel (trad.). 2a ed. São Paulo: Atlas, 2015.

MADDALENA, Paolo. I beni comuni nel codice civile, nella tradizione romanistica e nella Costituzione della Repubblica italiana, disponível em. Disponível em: <http://www.eurasia-rivista.org/i-beni-comuni-nel-codicecivile-nella-tradizione-romanistica-e-nella-costituzione-della-repubblicaitaliana/11508/>. Acesso em: 12 nov. 2016.

MAQUIAVEL, Nicolau. O Príncipe. DIAS, Maurício Santana (trad.). Dos apêndices de Luiz A. de Araújo. São Paulo, 2010.

MAQUIAVEL, Nicolau; Discursos sobre a primeira década de Tito Lívio; tradução MF; glossário e revisão técnica Patrícia Fontoura Aranovich; ${ }^{\text {a }}$ 
ed.; Martins Fontes; São Paulo, 2007.

MATTEI, Ugo. Beni comuni: un manifesto. $1^{\text {a }}$ ed. Roma-Bari: Editora Laterza \& Figli Spa, 2012.

MATTEI, Ugo; NADER, Laura. Pilhagem: Quando o Estado de Direito é ilegal. CAMARGO, Jefferson Luiz (Trad.). $1^{\text {a }}$ ed. São Paulo: Martins Fontes, 2013.

MEIRELLES, Hely Lopes. Direito de Construir, Malheiros. $10^{\mathrm{a}}$ ed., São Paulo. 2011.

MELLO, Bernardo. Trajeto da Maratona da Rio 2016 será testado com obras e em evento esvaziado. Disponível em: <

http://oglobo.globo.com/esportes/trajeto-da-maratona-da-rio-2016-sera-

testado-com-obras-evento-esvaziado-19040227>. Acesso em: 29 out. 2016.

MELLO, Celso Antônio Bandeira de. Curso de Direito Administrativo. 30a ed. São Paulo: Malheiros, 2012.

MINISTERO DELLA GIUSTIZIA. Relatório sobre a Comissão Rodotà para reforma das normas do Código Civil em matéria de bens públicos. 14 jun. 2007. Disponível em:

$<$ http://www.giustizia.it/giustizia/it/mg_1_12_1.wp?previsiousPage=mg_1_ 12\&contentId $=$ SPS 47617>.

MORAES, Alana et al.. Junho: potência das ruas e das redes. $1^{\text {a }}$ ed. São Paulo: Friedrich, Ebert, Stiftung, 2014.

NEGRI, Antonio. O poder constituinte: ensaio sobre as alternativas da modernidade. PILATTI, Adriano (Trad.). $2^{\mathrm{a}}$ ed. Rio de Janeiro: Lamparina, 2015.

NETO, Claudio Pereira de Souza. SARMENTO, Daniel. Direito Constitucional: teoria, história e métodos de trabalho. $2^{\text {a }}$ ed. Belo Horizonte: Fórum, 2014.

PEDERSEN, J. Martin The Commoner, $n^{\circ} 14$, inverno de 2010. Disponível em: $\quad<$ https://commoning.files.wordpress.com/2010/12/the-commoner14-winter-2010-chapter2.pdf $>$. Acesso em: 05 out. 2016. 
PEREIRA, Caio Mário da Silva. Instituições de Direito Civil. Direitos Reais IV. $21^{\text {a }}$ ed. Rio de Janeiro: Forense, 2013.

PEREIRA, Caio Mário da Silva. Instituições de Direito Civil. Introdução ao Direito Civil/Teoria geral de Direito Civil V.I. $25^{\mathrm{a}}$ ed. Rio de Janeiro: Forense, 2012.

PERLINGIERI, Pietro. Manuale di Diritto Civile. $6^{\mathrm{a}}$ ed. Napoli. Edizioni Scientifiche Italiane, 2007.

PERLINGIERI, Pietro. Perfis do Direito Civil: Introdução ao Direito Civil Constitucional. Maria Cristina de Cicco (Trad.). $3^{\mathrm{a}}$ ed. Renovar, 2007.

PILATTI, Adriano. A plebe multutidinária e a constituição de seus tribunos na sociedade global. $\mathrm{n}^{\mathrm{o}}$ 34. Revista Direito, Estado e Sociedade. Departamento de Direito da PUC-Rio

PILATTI, Adriano. Entrevista ao IHU Unisinos. Disponível em: $<$ http://www.ihu.unisinos.br/entrevistas/525872-o-regime-militar-naoacabou-nas-periferias->. Acesso em: 12 de novembro de 2016.

PILATTI, Adriano; $\mathrm{O}$ ano das maravilhas e do pesadelo, publicado em COCCO, Giuseppe e CAVA, Bruno (org.) Amanhã vai ser maior: O levante da multidão no ano que não terminou. $1^{\mathrm{a}}$ ed. Annablume: São Paulo, 2014.

PUFF, Jefferson. Como é que você vai botar pobre ali? Diz bilionário "dono" da Barra da Tijuca. Disponível em:

$<$ http://www.bbc.com/portuguese/noticias/2015/08/150809_construtora_oli mpiada_jp>. Acesso em: 12 nov. 2016.

RICCI, Rudá; ARLEY, Patrick. Nas Ruas: A outra política que emergiu em junho de 2013. Belo Horizonte: Editora Letramento, 2014.

RODOTÀ, Stefano. Il terribile diritto: Studi sulla proprietà privata e i beni comuni. $3^{\mathrm{a}}$ ed. Bologna: Società editrice il Mulino, 2013. p.

SANTOS. Mariana Corrêa dos. Corpos em Movimento: Black Block Carioca e Representações de Resistência. Amanhã vai ser maior: O levante da multidão no ano que não terminou. $1^{\mathrm{a}}$ ed. Annablume: São Paulo, 2014. 
SENADO. Lei ${ }^{\circ}$ 13.260/2016, de 17 de março de 2016. Lei Antiterrorismo é Sancionada Com Vetos Pela Presidente Dilma. Brasil, 17 mar. 2016. Disponível em:

$<$ http://www12.senado.leg.br/noticias/materias/2016/03/18/leiantiterrorismo-e-sancionada-com-vetos-pela-presidente-dilma $>$. Acesso em: 19 nov. 2016.

SILVA, Valeska S. Rodrigues. A Política da Multidão: a Constituição da Democracia do Comum no Pensamento de Antonio Negri. Rio de Janeiro. 2014. (Dissertação de Mestrado) - Departamento de Direito da PUC-Rio; Dissertação apresentada no programa de Mestrado em Teoria do Estado e Direito Constitucional da PUC-Rio sob orientação do Prof. Adriano Pilatti em 2014.

THE GUARDIAN Disponível em: $<$ https://www.theguardian.com/cities/2016/jul/11/rio-mayor-eduardo-paes2016-olympics>. Acesso em: 29 out. 2016.

VAINER, Carlos; OLIVEIRA, Nelma Gusmão. Megaeventos no Brasil e no Rio de Janeiro: Uma articulação transescalar na produção da cidade de exceção. In: SÁNCHEZ Et al.. (org). A Copa do Mundo e as Cidades: Políticas, Projetos e Resistências. Niterói: Editora UFF.

VIRNO, Paolo; Gramática da Multidão: para uma análise das formas de vida contemporâneas; São Paulo; Annablume, 2013, 1ª ed.

VIVA A VILA AUTÓDROMO. Disponível em:

$<$ https://vivaavilaautodromo.org/historia_de_luta/ $>$. Acesso no dia 29/07/2016. 